\title{
Microstructures and deformation mechanisms in Opalinus Clay: insights from scaly clay from the Main Fault in the Mont Terri Rock Laboratory (CH)
}

\author{
Ben Laurich ${ }^{1, a}$, Janos L. Urai ${ }^{1}$, and Christophe Nussbaum ${ }^{2}$ \\ ${ }^{1}$ Structural Geology, Tectonics and Geomechanics, RWTH Aachen University, Lochnerstr. 4-20, 52056 Aachen, Germany \\ ${ }^{2}$ Mont Terri Consortium, Federal Office of Topography swisstopo, Route de la Gare 63, 2882 St-Ursanne, Switzerland \\ a now at: Federal Institute for Geosciences and Natural Resources (BGR), Stilleweg 2, 30655 Hannover, Germany
}

Correspondence to: Ben Laurich (ben.laurich@bgr.de)

Received: 29 June 2016 - Published in Solid Earth Discuss.: 11 July 2016

Revised: 14 November 2016 - Accepted: 13 December 2016 - Published: 10 January 2017

\begin{abstract}
The Main Fault in the shaly facies of Opalinus Clay is a small reverse fault formed in slightly overconsolidated claystone at around $1 \mathrm{~km}$ depth. The fault zone is up to $6 \mathrm{~m}$ wide, with micron-thick shear zones, calcite and celestite veins, scaly clay and clay gouge. Scaly clay occurs in up to $1.5 \mathrm{~m}$ wide lenses, providing hand specimens for this study. We mapped the scaly clay fabric at $1 \mathrm{~m}-10 \mathrm{~nm}$ scale, examining scaly clay for the first time using broad-ion beam polishing combined with scanning electron microscopy (BIBSEM). Results show a network of thin shear zones and microveins, separating angular to lensoid microlithons between $10 \mathrm{~cm}$ and $10 \mu \mathrm{m}$ in diameter, with slickensided surfaces. Our results show that microlithons are only weakly deformed and that strain is accumulated by fragmentation of microlithons by newly formed shear zones, by shearing in the micronthick zones and by rearrangement of the microlithons.

The scaly clay aggregates can be easily disintegrated into individual microlithons because of the very low tensile strength of the thin shear zones. Analyses of the microlithon size by sieving indicate a power-law distribution model with exponents just above 2 . From this, we estimate that only $1 \mathrm{vol} \%$ of the scaly clay aggregate is in the shear zones.

After a literature review of the hypotheses for scaly clay generation, we present a new model to explain the progressive formation of a self-similar network of anastomosing thin shear zones in a fault relay. The relay provides the necessary boundary conditions for macroscopically continuous deformation. Localization of strain in thin shear zones which are locally dilatant, and precipitation of calcite veins in di-
\end{abstract}

latant shear fractures, evolve into complex microscale repartitioning of shear, forming new shear zones while the microlithons remain much less deformed internally and the volume proportion of the $\mu$ m-thick shear zones slowly increases. Grain-scale deformation mechanisms are microfracturing, boudinage and rotation of mica grains, pressure solution of carbonate fossils and pore collapse during ductile flow of the clay matrix. This study provides a microphysical basis to relate microstructures to macroscopic observations of strength and permeability of the Main Fault, and extrapolating fault properties in long-term deformation.

\section{Introduction}

Scaly clay is an enigmatic soft rock with important differences in rheological and hydrological behaviour compared to its more competent protolith (sensu Rutter et al., 2001). There have been many studies of scaly clays, because of their geotechnical importance and role in detachment faulting. A rock comprises a scaly fabric if it splits along an anastomosing network of fractures into smaller rock pieces, so-called microlithons (sensu Passchier and Trouw, 2005). Scaly clay is generally seen to have formed by deformation, and occurs in several fault settings (cf. Vannucchi et al., 2003), such as in drill cores from décollement zones of clay-rich accretionary prisms: Barbados (Labaume et al., 1997; Maltman et al., 1997; Takizawa and Ogawa, 1999) and more recently Tohoku (Chester et al., 2013; Ujiie et al., 2013). Several other 
(a)

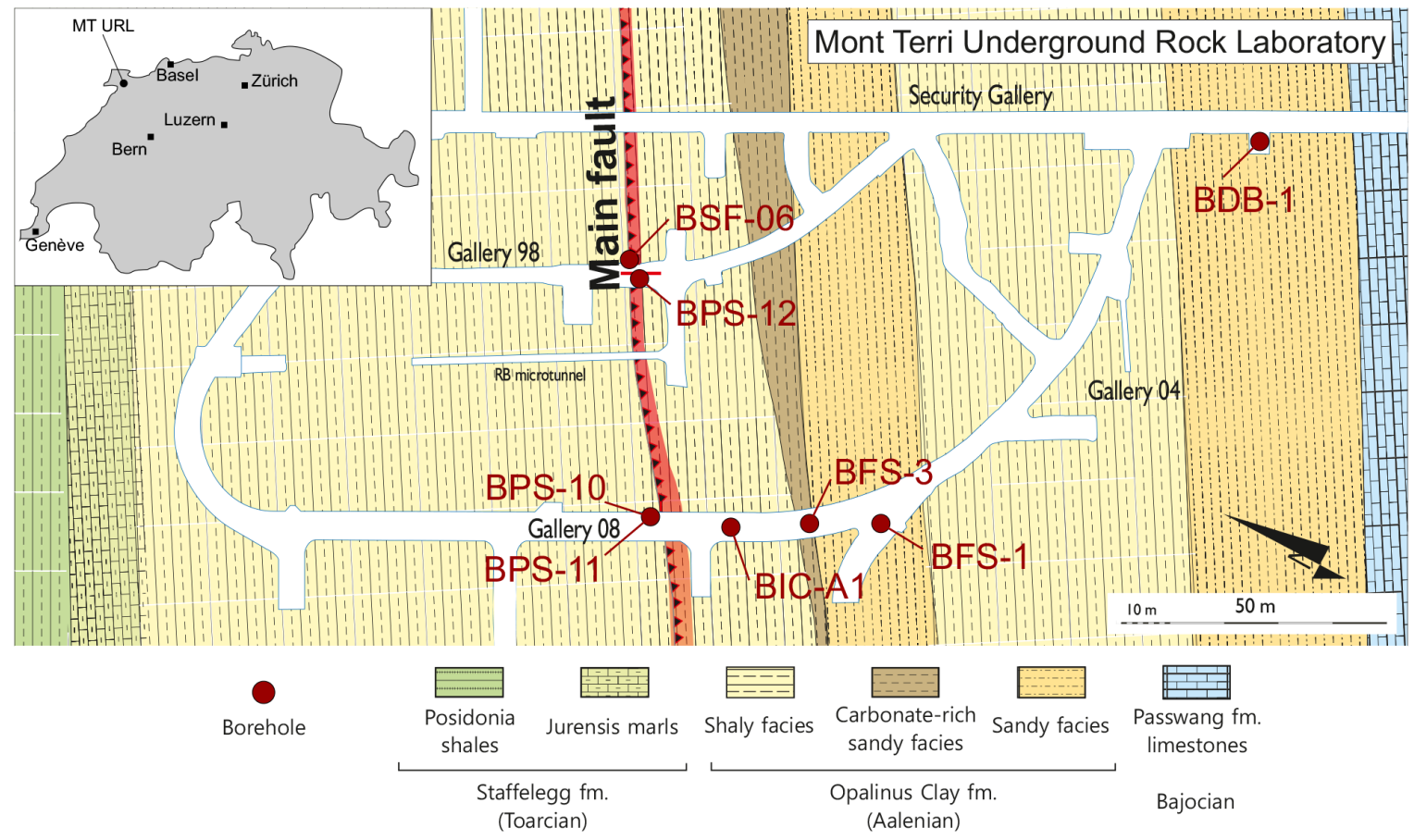

(b)

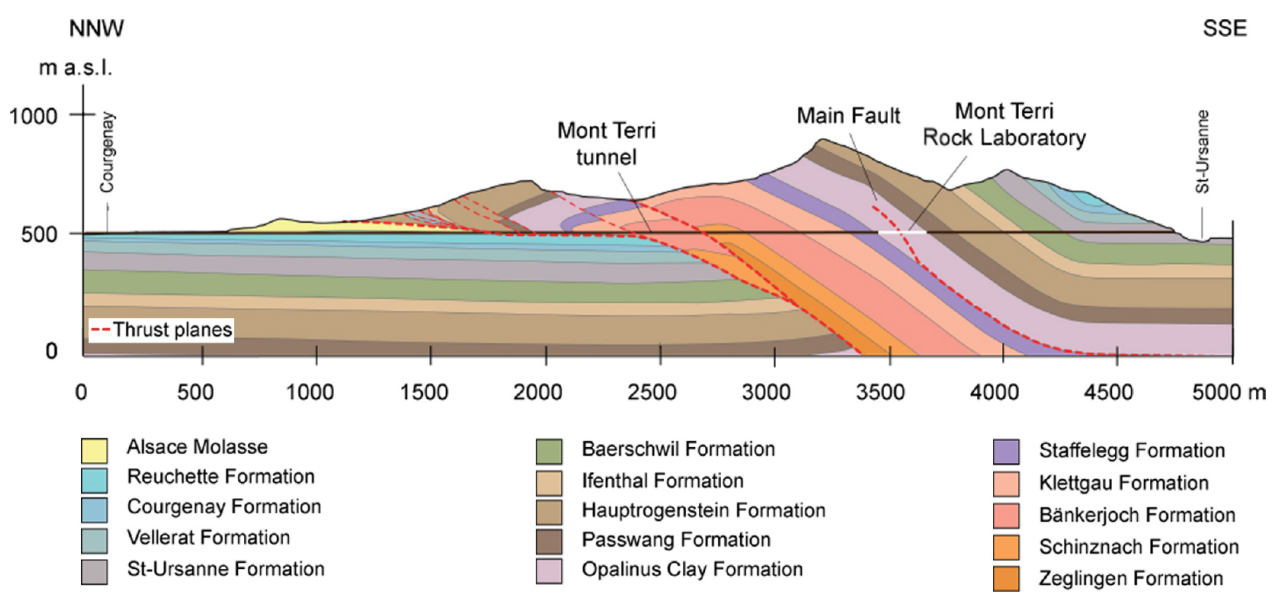

Figure 1. Geology of the Mont Terri Rock Laboratory (CH). (a) Outline and facies map (plan view); borehole locations indicated. (b) 2-D balanced cross section after Nussbaum et al. (2017).

studies do not use the term scaly clay; however, the rocks described contain complex shear zone arrays between microlithons - a fabric termed "scaly clay" by other authors (e.g. Arch and Maltman, 1990; Ismat, 2013; Maltman, 1987; Vitone et al., 2013; Vollmer and Bosworth, 1984).

Due to its fragile nature, intact scaly clay is difficult to sample and commonly weathered in surface outcrops. The Mont Terri Rock Laboratory in Switzerland offers a world class site with excellent sampling conditions of wellpreserved scaly clay.

We studied scaly clay from the so-called Main Fault in the shaly facies of Opalinus Clay (OPA) at the Mont Terri Rock Laboratory (Fig. 1). We observed five major fault struc- tures: (1) slickensides on fractured surfaces, which are in cross-sectional view associated with (2) $\mu \mathrm{m}$-thin shear zones of slickenside-parallel-oriented particles, (3) clay gouge, (4) calcite and celestite veins and (5) scaly clay aggregates. In a first publication, Laurich et al. (2014) focused on the evolution of veins and thin shear zones in the damage zone of the Main Fault, and showed strong particle reorientation and collapse of porosity due to deformation. The paper proposed that the scaly clay evolved by the progressive development of an anastomosing network of micro-shear zones. In this article, we present detailed observations of the scaly clay aggregates to document the geometry, size distribution and microstruc- 


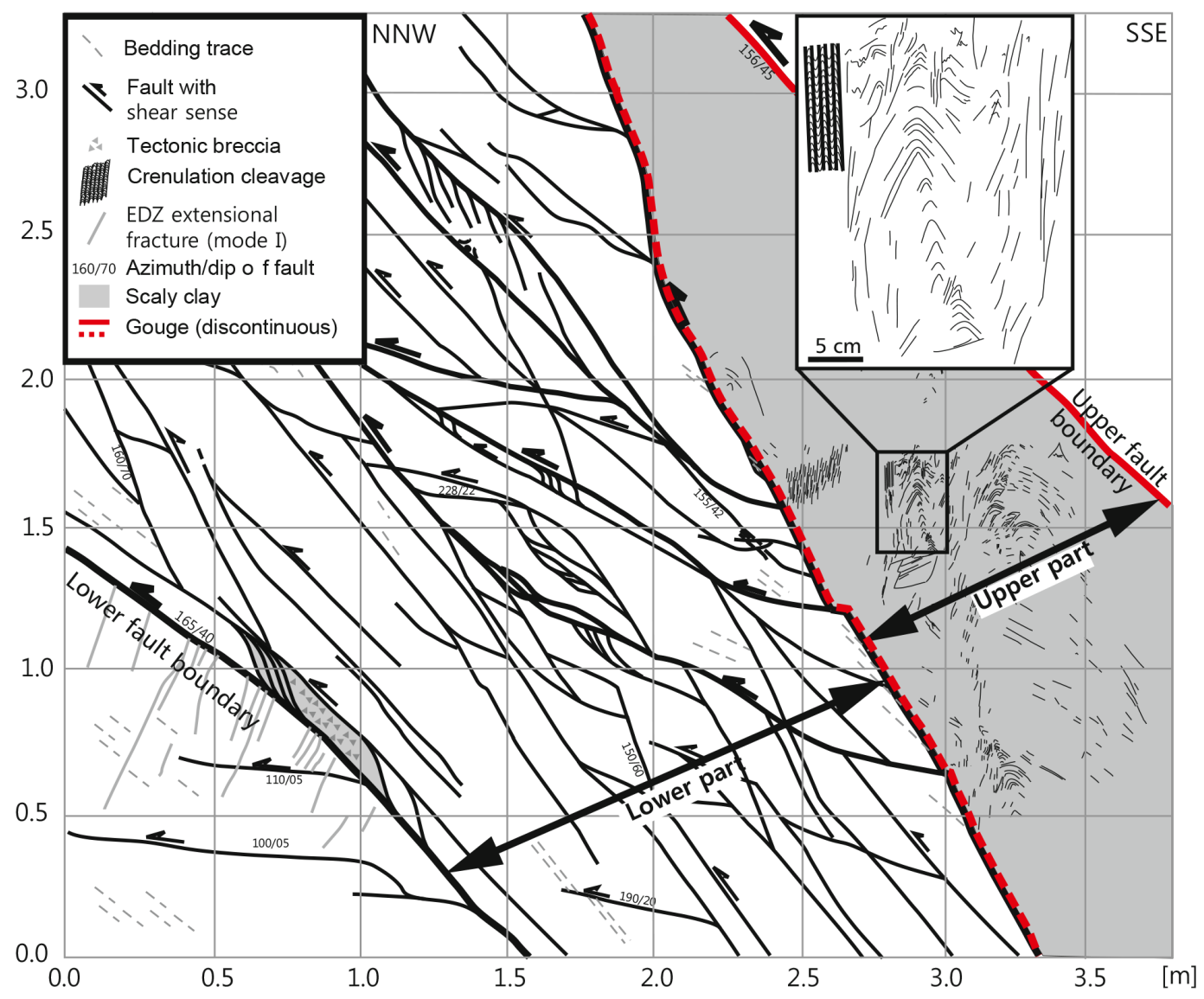

Figure 2. Small-scale map of the Main Fault in Gallery 08, viewing direction ENE; see Fig. 1 for the location (modified after Nussbaum et al., 2011).

ture of microlithons, shear zones and microveins, on which we base a model for the evolution of scaly clay in this setting.

The Main Fault is a 1 to $6 \mathrm{~m}$ wide fault zone (Fig. 2). It is interpreted as a reverse fault with about $10 \mathrm{~m}$ offset. Due to the fault-bend folding of the Mont Terri anticline, the Main Fault was passively steepened from 20 to $45^{\circ}$. It developed during the late Miocene (Nussbaum et al., 2011, 2017) at temperatures below $55^{\circ} \mathrm{C}$ in a slightly overconsolidated protolith, after burial to $1350 \mathrm{~m}$ in the late Cretaceous (Mazurek et al., 2006). Packer tests yielded hydraulic conductivities of $2 \times 10^{-13} \mathrm{~m} \mathrm{~s}^{-1}$ for the protolith and $1 \times 10^{-12}$ to $1 \times 10^{-13} \mathrm{~m} \mathrm{~s}^{-1}$ for the Main Fault (Bossart and Wermeille, 2003; Thury and Bossart, 1999). Profiles of several porewater geochemical tracers are not perturbed across the Main Fault (Mazurek et al., 2011; Pearson et al., 2003; Rübel et al., 2002). This indicates diffusion as the main transport mechanism acting at least since the onset of influx from meteoric waters (Bossart and Wermeille, 2003): the Main Fault at present is of very low permeability and provides a welldocumented example of a sealing fault in claystone.

\section{Methods}

We collected hand specimens from the outcrop walls in galleries 08 and 98 in the Mont Terri Rock Laboratory (Fig. 1) as well as from six fault-penetrating drill cores (BPS12, BPS13, BPS14, BFS1, BFS2 and BFS3). Sampling and detailed field observations were based on field maps of the outcrop (Fig. 2). Where possible, the sample orientation was marked and slickenside orientation noted.

On site, the scaly clay samples were treated in two ways: (1) stabilization in vacuum-sealed bags or resin impregnation for transport or (2) gentle disintegration by hand into microlithons which were much harder and did not disintegrate, separating the product into large ( $\mathrm{cm}$-size) and small fractions by hand, photographing the result and packing in plastic bags.

After unpacking, all intact samples (1) were resin stabilized, diamond-cut dry parallel to slickensides (by visual observation these had a clear preferred orientation consistent with the fault's inferred movement direction) and perpendicular to the main foliation, and polished dry with carbide papers. One of the two polished halves was decorated by con- 
Outcrop / drillcore mapping Sample selection

Outcrop / drillcore sampling

\begin{tabular}{|c|c|}
\hline Sample type 1 & Sample type 2 \\
\hline $\begin{array}{c}\text { Sample stabilization } \\
\text { Short water immersion } \\
\text { Photography, RLM } \\
\text { Foliae segmentation } \\
\text { BIB-SEM }\end{array}$ & $\begin{array}{c}\text { Sample disintegration } \\
\text { Sieving } \\
\text { Photography, RLM } \\
\text { Particle analysis (DIA) } \\
\text { BIB-SEM }\end{array}$ \\
\hline
\end{tabular}

Figure 3. Sample types and corresponding workflow (RLM: reflected light microscopy; DIA: digital image analysis; BIB: broadion beam; SEM: scanning electron microscopy).

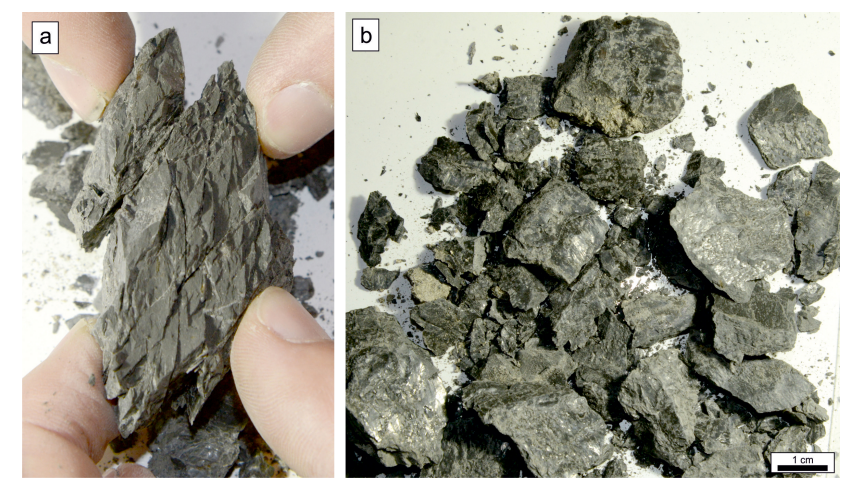

Figure 4. Intact scaly clay sample A5 (a) and loose flakes (b) after gentle disintegration by hand.

tact with water for a few seconds and quick drying in air. This technique caused a sight differential swelling of the polished surface, so that foliations and shear zones became visible in reflected light, and could be photographed with a resolution of $0.05 \mathrm{~mm}$ to provide a basis for manual interpretation of bedding and shear zones.

In the disintegrated samples (2), microlithon size fractions of the samples were measured by gentle sieving (mesh sizes between 8 and $0.063 \mathrm{~mm}$ ). Subsequently, the morphology and microstructure of selected microlithons were analysed. Size distributions of microlithons in each sieve fraction were measured by separating a small subsample of each sieve fraction, dispersing the microlithons on a white paper sheet and digital image analysis (DIA) using the routines analyse particles and minimum bounding geometry of software Fiji 1.5b and ArcGIS 10.2. The representativeness of the subsampling was aspired by the cone and quartering technique (Brittain, 2002). The total number of microlithons per sieve fraction was then estimated by multiplying by the weight ratio of the sieve fraction and the subsample. We carried this out for microlithon size fractions down to $0.25 \mathrm{~mm}$ in diameter.
For detailed microstructural study, we used microlithons from all size fractions and intact hand specimens (those halves of the samples which were kept dry). These subsamples were broad-ion-beam (BIB) polished (cf. Desbois et al., 2009; Hemes et al., 2013; Houben et al., 2013; Klaver et al., 2012; Laurich et al., 2014) and subsequently imaged with a Zeiss supra 55 scanning electron microscope (SEM). The BIB polishing removed $100 \mu \mathrm{m}$ of sample material to create $2 \mathrm{~mm}^{2}$ flat surfaces $( \pm 5 \mathrm{~nm}$ roughness as determined by Klaver et al., 2012), free of mechanical polishing artefacts. We used a JEOL SM09010 Ar-BIB cross-section polisher operating at $6 \mathrm{kV}$ and $150-200 \mu \mathrm{A}$ for $8 \mathrm{~h}$. Sample V12-1 was polished using a Tic3x Leica Ar-BIB operating for $1.5 \mathrm{~h}$ at $7-3 \mathrm{kV}$ with up to $2.3 \mathrm{~mA}$. Moreover, we used reflected light microscopy (RLM) using a Zeiss Axiovison microscope with magnifications up to $10 \times$. For multi-scale analysis, we stitched RLM and SEM micrographs into large mosaics of up to 250 individual images using the Autopano version 2.6 software.

All methods were applied with great care in handling and, except for the water immersion technique, always without the use of water. Larger fractures did form along pre-existing shear zones, always showing slickenlines on the fracture walls if separated. Such larger fractures in mudstones were interpreted as artefacts from unloading and/or from desiccation (Dehandschutter et al., 2005; Houben, 2013). Other artefacts were not observed.

Applying these methods (cf. Fig. 3), we obtained the following data: (1) digitized vector networks of bedding foliation and shear zones, (2) microlithon size distributions of two disintegrated hand specimens and (3) BIB-SEM and BIBRLM images of the microstructure of intact scaly clay aggregates and disintegrated scaly clay microlithons.

We present first our results on microlithon size distributions and microlithon microstructure followed by a calculation of the vol \% of strained material and by a detailed description of shear zone geometries in scaly clay.

\section{Results}

Scaly clay from the Mont Terri Rock Laboratory is present in the outcrop walls and in some drill cores of the Main Fault. Fig. 4a shows an intact sample that is easily disintegrated into fragments (Fig. 4b). These fragments can at first be further disintegrated by gentle hand manipulation. The residual microlithons are much harder to break. After disintegration, all microlithons reveal shiny slickensides (Figs. 4b, 6), showing that the sample invariably disintegrated along pre-existing, non-cohesive shear zones. The largest sampled microlithons are about $7 \mathrm{~cm}$ long. 
(a)

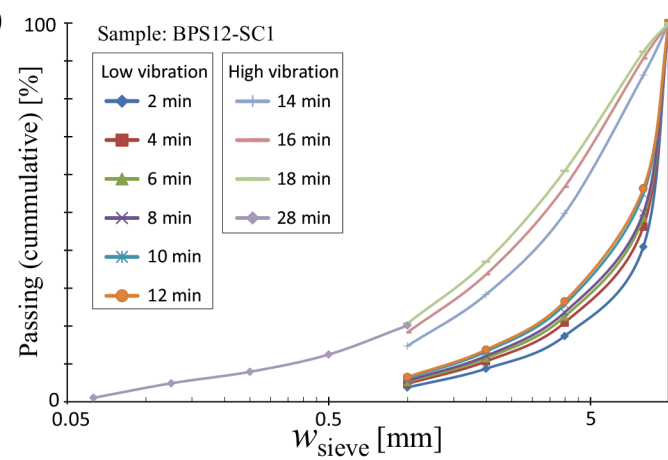

(c)

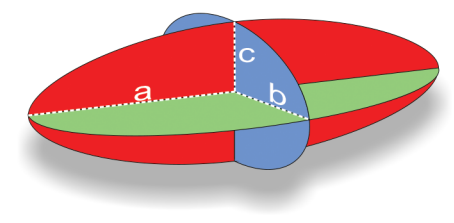

(b)

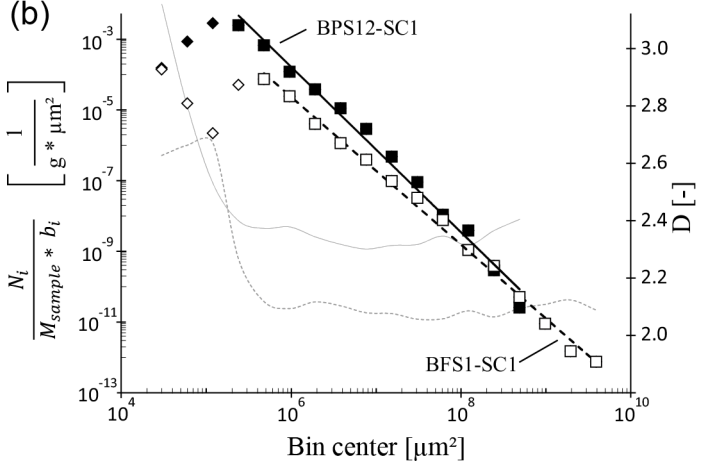

(d)

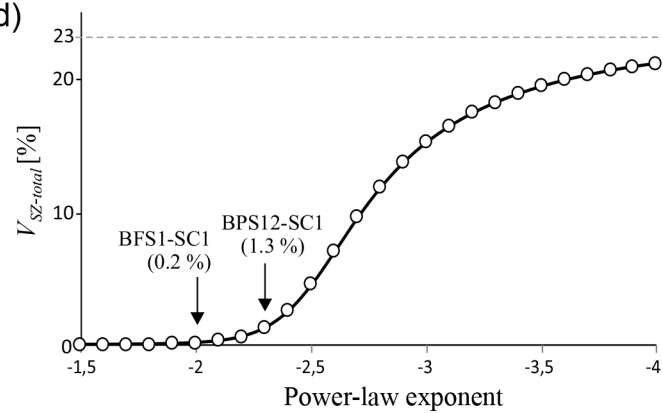

Figure 5. (a) Cumulative sieving curves of scaly clay microlithons from sample BPS12-SC1. (b) Log-log diagram illustrating the frequency of microlithon area sizes for samples BPS12-SC1 and BFS1-SC1. The frequency $\left(N_{i}\right)$ is noted corresponding to bin width $\left(b_{i}\right)$ and normalized for sample mass $\left(M_{\text {sample }}\right)$; the $x$ axis displays the bin centre. Diamonds are data points excluded in the regression analysis. Thick, black lines are power-law regression curves. Thin, grey lines give the interpolated local slope as noted on the right axis. The local slope curves show constant values for the chosen range of regression, indicating that the power-law model is a good fit for the data trend and validating that the determined power-law exponents are correct. Solid lines correspond to sample BPS12-SC1, dashed lines to sample BFS1-SC1. (c) Strongly simplified generic microlithon shape (ellipsoid). (d) Sensitivity of the power-law exponent to calculated total shear zone volume ( $\left.V_{\mathrm{SZ} \text {-total }}\right)$. See text for details.

\subsection{The size distribution of microlithons}

The size distributions of scaly clay microlithons were determined in two samples: BPS12-SC1 and BFS1-SC1 (cumulative sieving weights 605.2 and $508.1 \mathrm{~g}$, respectively). They were retrieved from drill cores BPS12 and BFS1 (Fig. 1). Both samples were slightly disintegrated by hand prior to sieving. The size of the flakes decreased further during the sieving procedure, as the flakes disintegrated into progressively smaller microlithons. Figure 5 a gives the measured sieve fraction weights for sample BPS12-SC1. The weighing was repeated after every 2 min of sieving. With increasing sieving time and with increasing vibration energy, the smaller fractions increased in weight as more large particles were divided into smaller microlithons (Fig. 5a). As the weighing curves did not significantly change after $10 \mathrm{~min}$ of sieving, the vibration intensity was increased from 1.2 to $1.8 \mathrm{~mm}$ vibration amplitude. This stronger vibration enhanced the microlithon disintegration, but may also have resulted in microlithon abrasion. Because the results of 4 to 6 min of highvibration sieving differ only slightly, the sieving was stopped. We interpret this as showing that this treatment largely dis- integrated the aggregate into its microlithons, without creating too many small particles by abrasion. This is supported by RLM and SEM, which shows the vast majority of microlithons being bound by shear zones which fracture into polished slickensided surfaces (Fig. 6).

The moisture state significantly affects properties and behaviour of OPA (e.g. Amann and Vogelhuber, 2015). For sample BPS12-SC1, we investigated whether an increased moisture state enhances the aggregate disintegration along shear zones. We kept the sample next to a cup of water in an air-sealed container for 1 night at room temperature. During subsequent disintegration by hand, BPS12-SC1 did not appear to behave differently compared to other aggregates stored at room humidity. The sample weight during this night increased from 609.0 to $610.2 \mathrm{~g}$. The sieving procedure took place immediately after removing the sample from the airtight container. The cumulative weight of all sieve fractions was $605.2 \mathrm{~g}$. The decrease of $0.8 \mathrm{wt} \%$ during the sieving can be attributed to the evaporation of sample moisture and to the generation of fine dust. Both processes have a stronger impact on the smaller sieving fractions, due to their increased 

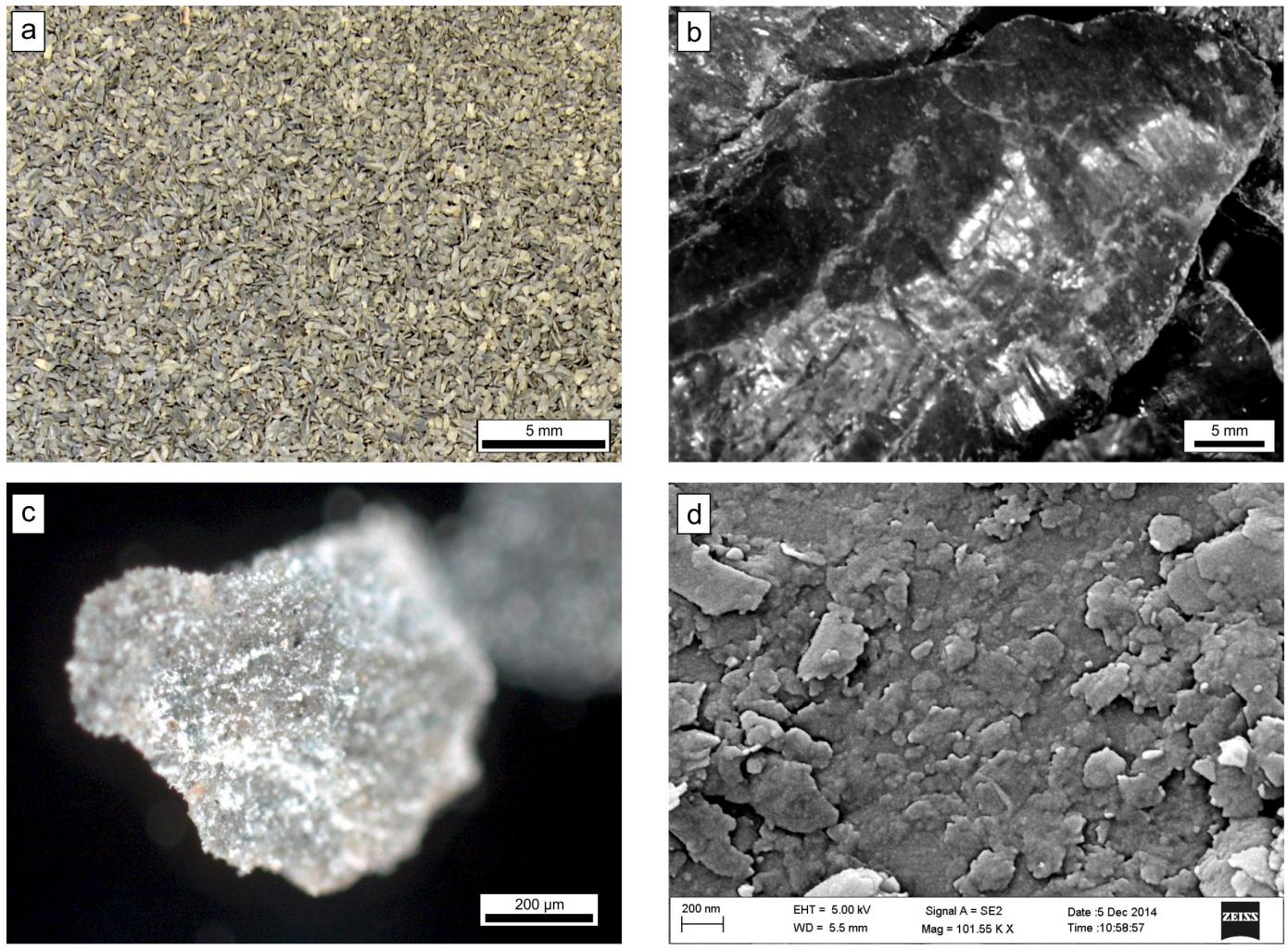

Figure 6. (a) Photograph of microlithons which passed the $0.25 \mathrm{~mm}$ but not the $0.125 \mathrm{~mm}$ sieve. Note the smooth, polished slickensided surface of the microlithons (b and c). (d) shows the surface in high-resolution SEM to be composed of elongated clay particles, which are only tens of nm wide and oriented parallel to the surface. This structure is identical to slickensided surfaces presented in Laurich et al. (2014).
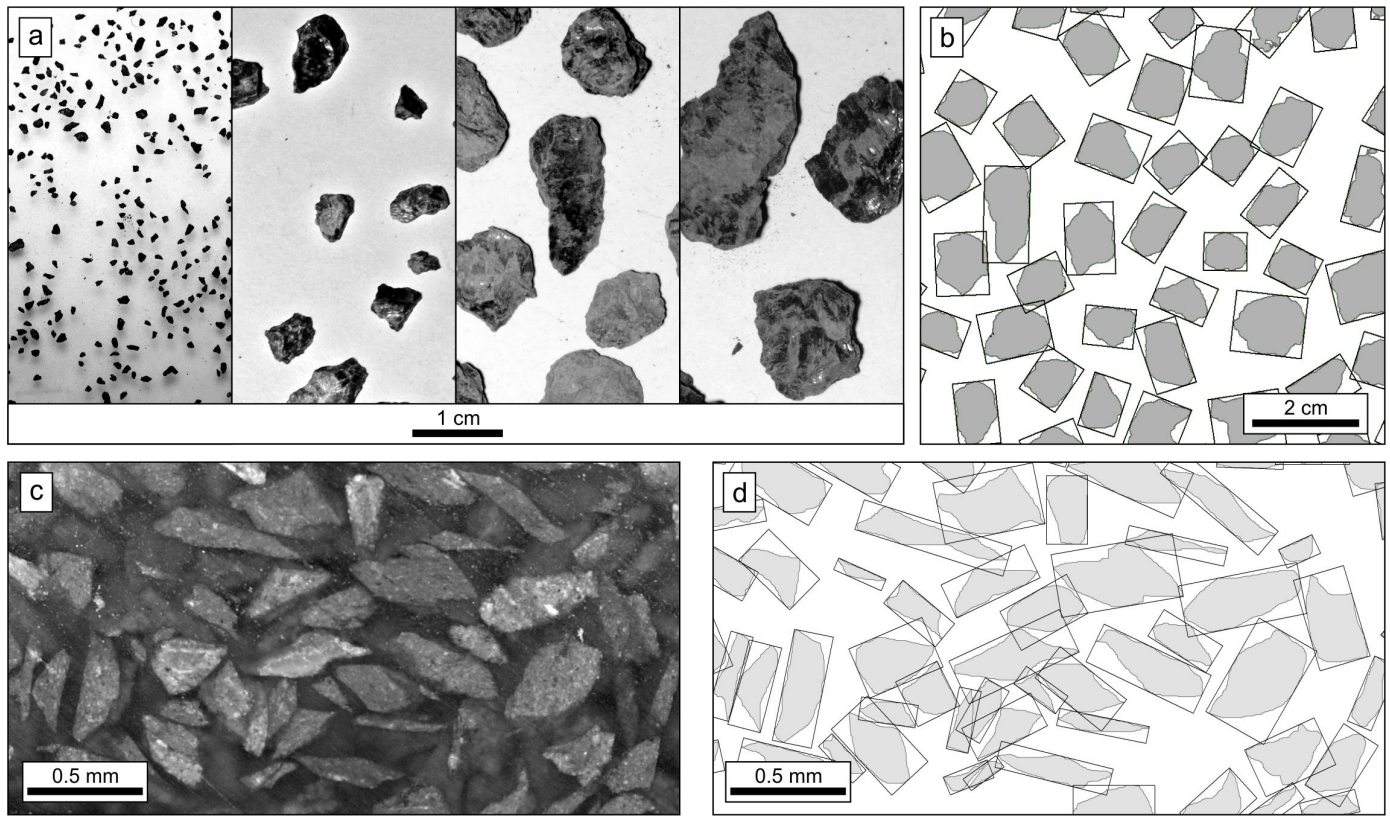

Figure 7. Disintegrated microlithons (a and c) and corresponding DIA segmentations with minimum bounding rectangles for shape description (b and d). (a) Photographs of dispersed microlithons of different sieve fractions. (c) is a reflected light micrograph showing resinembedded microlithons from the 800 to $400 \mu \mathrm{m}$ sieve fractions. See text for details. 
surface-to-mass ratio. The evaporation and the dust generation per sieve fraction would be very difficult to determine. Plus, we consider the overall weight loss of $0.8 \mathrm{wt} \%$ to be minor. Hence, we did not correct for these effects; i.e. we used the sieve fraction weights as measured.

After the sieving procedure, subsamples of the sieved fractions were analysed with DIA. This analysis yielded number and area sizes of the microlithons in each subsample. From this, histograms were created for each subsample, showing microlithon frequencies vs. microlithon area. The bin size of the histograms was chosen to increase exponentially, as the microlithon area sizes are power-law distributed (cf. Bonnet et al., 2001). All resulting histograms were then combined, weighted by the ratio of subsample mass to total mass of a sieve size. This yielded an estimation of the total microlithon size distribution for each sample: BPS12-SC1 and BFS1-SC1. The log-log diagram in Fig. 5b displays these estimations in a histogram of microlithon frequencies $\left(\mathrm{Nn}_{i}\right)$ vs. microlithon area, i.e. bin centre $\left(\mathrm{bc}_{i}\right)$. Therein, the counted frequencies $\left(N_{i}\right)$ are (1) noted with respect to bin width $\left(b_{i}\right)$, which is exponentially increasing, and (2) normalized by the total sample mass $\left(M_{\text {sample }}\right)$ to ensure inter-sample comparability:

$\mathrm{Nn}_{i}=\frac{N_{i}}{M_{\text {sample }} \times b_{i}} \quad\left[\frac{1}{\mathrm{~g} \times \mu \mathrm{m}^{2}}\right]$.

Moreover, Fig. 5b shows power-law regression lines (calculated by the least squares method on logarithmized data) for BPS12-SC1 (Eq. 2) and BFS1-SC1 (Eq. 3):

$y=2 \times 10^{10} \mathrm{bc}_{i}^{-2.34}, R^{2}=0.989$,

$y=8 \times 10^{7} \mathrm{bc}_{i}^{-2.09}, R^{2}=0.996$.

Frequencies of small area sizes deviate from the power-law trend (diamonds in Fig. 5b). These data points were excluded in the calculation of the regression lines, as we infer that electrostatic effects interfere with the separation of smaller microlithons. Additionally, small area microlithons are underrepresented due to the resolution limitations in DIA. However, we consider a lower limit of the regression of about $50 \mu \mathrm{m}$ in microlithon height, as BIB-SEM analyses show that the microlithons can be as small as a few grains (see below). The upper limit of the regression analysis is bound by the sample size of about $10 \mathrm{~cm}$. Larger microlithons may be found if one disintegrated a much larger (e.g. $50 \mathrm{~kg}$ ) sample (Figs. 2 and 14a).

The validity of the power-law model for the chosen range is approved by constant values in local slope (cf. Bonnet et al., 2001, and references therein), shown by the thin grey lines in Fig. 5b. Therein, the local slope $(D)$ is calculated by

$D=\frac{\log \left(\frac{\mathrm{Nn}_{i}}{a}\right)}{\log \left(\mathrm{bc}_{i}\right)}$, where $a$ is the factor of proportionality as given in the regression lines of Eqs. (2) and (3) $\left(2 \times 10^{10}\right.$ and $8 \times 10^{7}$ for BPS12-SC1 and BFS1-SC1, respectively).

The raw data of the sieving and the DIA as well as their processing are provided as the Supplement to this article.

\subsection{The microstructure of microlithons}

Surfaces of freshly separated microlithons of different sizes were imaged by SEM. All show slickensides which are indistinguishable from the surfaces of solitary slickensides described by Laurich (2015). The surfaces show locally matt patches (Fig. 7a), being more abundant on smaller microlithons. We interpret this as microscopic fragments formed during the disintegration and sieving process, attached to the surfaces by electrostatic forces. In a few cases, in cross section, microlithons show a few thin internal shear zones of parallel aligned clay minerals (Fig. 8). These zones indicate that not all microlithons are fully disintegrated.

Keeping the above arguments in mind, and considering the similar trend of power-law microlithon size distribution in both samples and the shiny surfaces, which bound the vast majority of the microlithons, we interpret these results to be a reasonable representation of the size distribution of the microlithons in the scaly clay of the Main Fault.

The flakes settle into a preferred orientation when embedded in resin, with their longest axes sub-horizontal. A cross section of resin-embedded microlithons was cut and examined by RLM (Fig. 7c). The shape of the microlithons $(X-Y$ section) derived from minimum bounding rectangle geometry (Fig. 7d), showing an average height-to-length ratio of $0.43, \pm 0.16$. In the vertical viewing direction (microlithons dispersed on a sheet of paper, Fig. 7a and b), a total of 206 microlithons show a width-to-length ratio of $0.71, \pm 0.12$.

At high-resolution SEM, all slickensides are smoothly polished, revealing platy, sub- $\mu$ m clay particles aligned parallel to the surface and the characteristic nanoparticles described in Laurich et al. (2015) (Figs. 6d, 9c and 10b). Thus, we infer the slickensided microlithon boundaries to be formed by fracturing of $\mu \mathrm{m}$-thin shear zones during sampling, such as reported in Laurich et al. (2014). Microlithon internal $\mu \mathrm{m}$ thin shear zones are shown exemplarily in Fig. 9d.

By BIB-SEM, we detect a microlithon internal fabric that is similar to undeformed fabric of OPA outside scaly clay. For comparison, Fig. 10b-c show details of scaly clay microlithons and Fig. 10a shows a detail of an undeformed subsample. We see similarities in grain size distribution, grain shape and grain orientation. Note also the isolated, dark and unstrained organic matter (OM) in both samples. Additionally, the preserved pores in siderites (Fig. 10c) are an indicator of unstrained fabric (Houben et al., 2013). Frequently, lobate $\mathrm{SiO}_{2}$ grain boundaries and truncated fossils suggest pressure solution precipitation, to a comparable degree in both, deformed and undeformed material (Fig. 10). We therefore interpret these features as being diagenetic mi- 

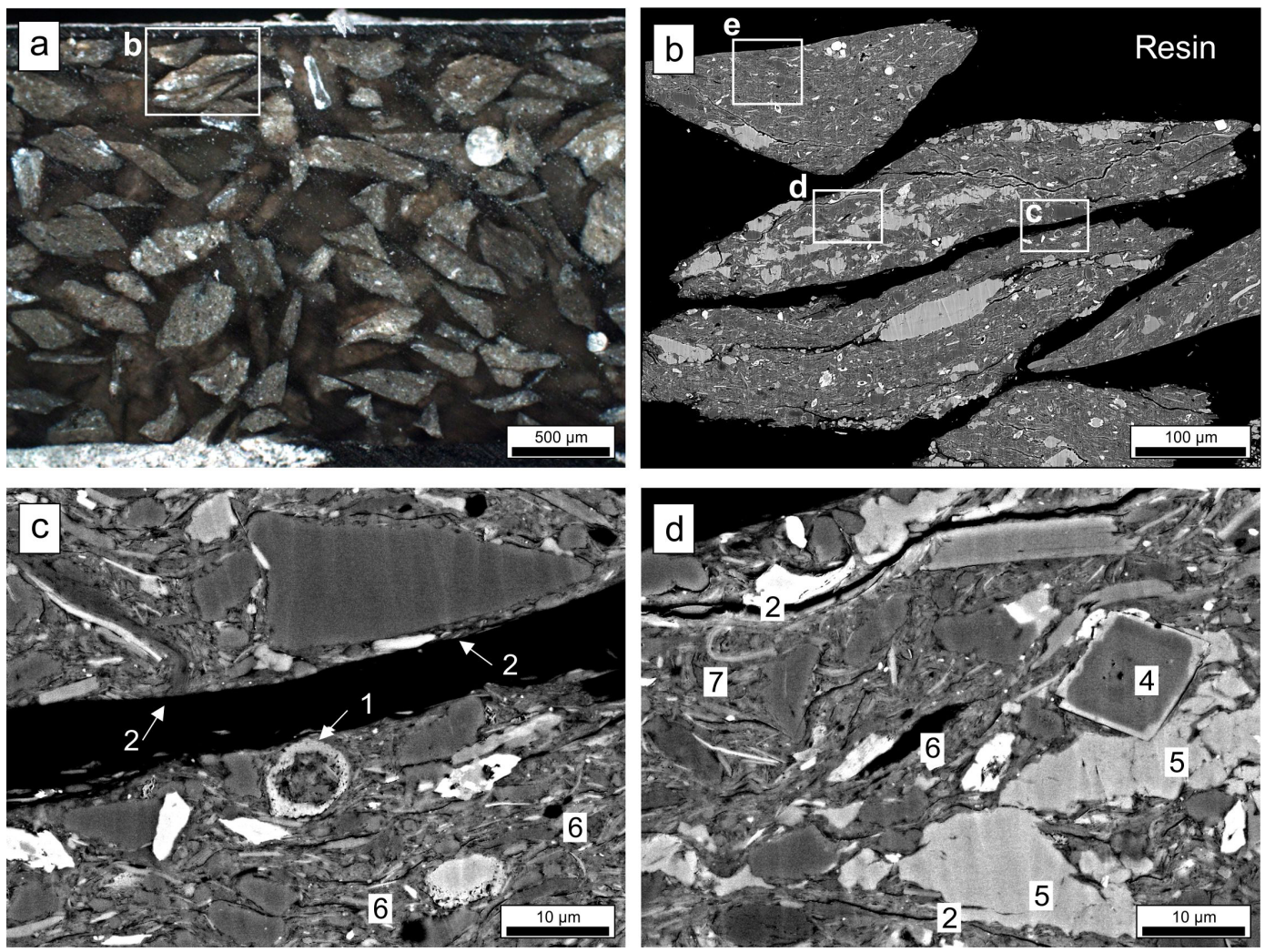

Figure 8. (a) shows resin-embedded microlithons in RLM. (b)-(d) are BIB-SEM micrograph insets of (a). (b) shows fractured microlithons and calcite veins (bright). (c) is a detail of (b) showing a thin, microlithon bounding shear zone (2), an intact fossil (1) and unstrained OM (dark black, 6). (d) is a detail of (b) showing microlithon internal shear zones (2), calcite overgrowth (4), calcite veins (5), strained OM (6) and bending of clay particles (bright mica, 7). Detail (e) is shown in Fig. 10b.

crostructures, generated at greater overburden than today (max. overburden is inferred to be $1350 \mathrm{~m}$; see references above). Fig. 8c shows an intact calcite fossil in a microlithon, supporting the interpretation of tectonically unstrained microlithons.

Despite this strong microstructural similarity, we also spotted some differences between protolith and microlithons. Locally, especially in the "tails" of the microlithons, there is evidence of microlithon internal deformation. First, and most obvious, are thin shear zones that cut the microlithons (Figs. 8 and 9). As stated above, this indicates that the scaly clay block is not fully disintegrated along all the in situ shear zones. Moreover, Fig. 10c suggests a higher fabric intensity compared to the undeformed sample, and we interpret this as caused by less localized deformation of microlithons. Further signs of microlithon internal deformation are overgrowth structures and an increased density of larger calcite patches and veins as shown in Fig. 8b and d. These patches and veins indicate pressure solution precipitation, complemented by percolation of additional fluids in order to provide the necessary calcium (Clauer et al., 2017). Moreover, we locally find particle bending and elongated OM particles in the vicinity of thin shear zones (Figs. 8-10). The calcite patches occur in geometric relation to microlithon internal shear zones. However, microlithon internal deformation alters the protolithic fabric only to a limited extent and is found to be localized in isolated zones, leaving large microlithon volumes unaffected.

\subsection{The vol \% of strained material in scaly clay}

Based on BIB-SEM micrographs, the shear bands that separate the microlithons are always in the range of a few $\mu \mathrm{m}$, whether the microlithon is small or large. Hence, with decreasing microlithon size, the vol \% of bounding shear zones per microlithon increases: the smallest microlithons consist of a large part of sheared clay; in contrast, the largest microlithons contain less than 1 vol\%o strained material. For a rough estimation of the total shear zone volume in an entire scaly clay aggregate $\left(V_{\mathrm{SZ} \text {-total }}\right)$, we extrapolated the regression of microlithon frequencies (Eqs. 2 and 3) for bins down to $5000 \mu \mathrm{m}^{2}$, which corresponds to the smallest microlithons found in BIB-SEM $(\sim 50 \mu \mathrm{m}$ in height). The calculated frequencies $\left(N_{i-\text { calc. }}\right)$ are then multiplied by the geometrically 

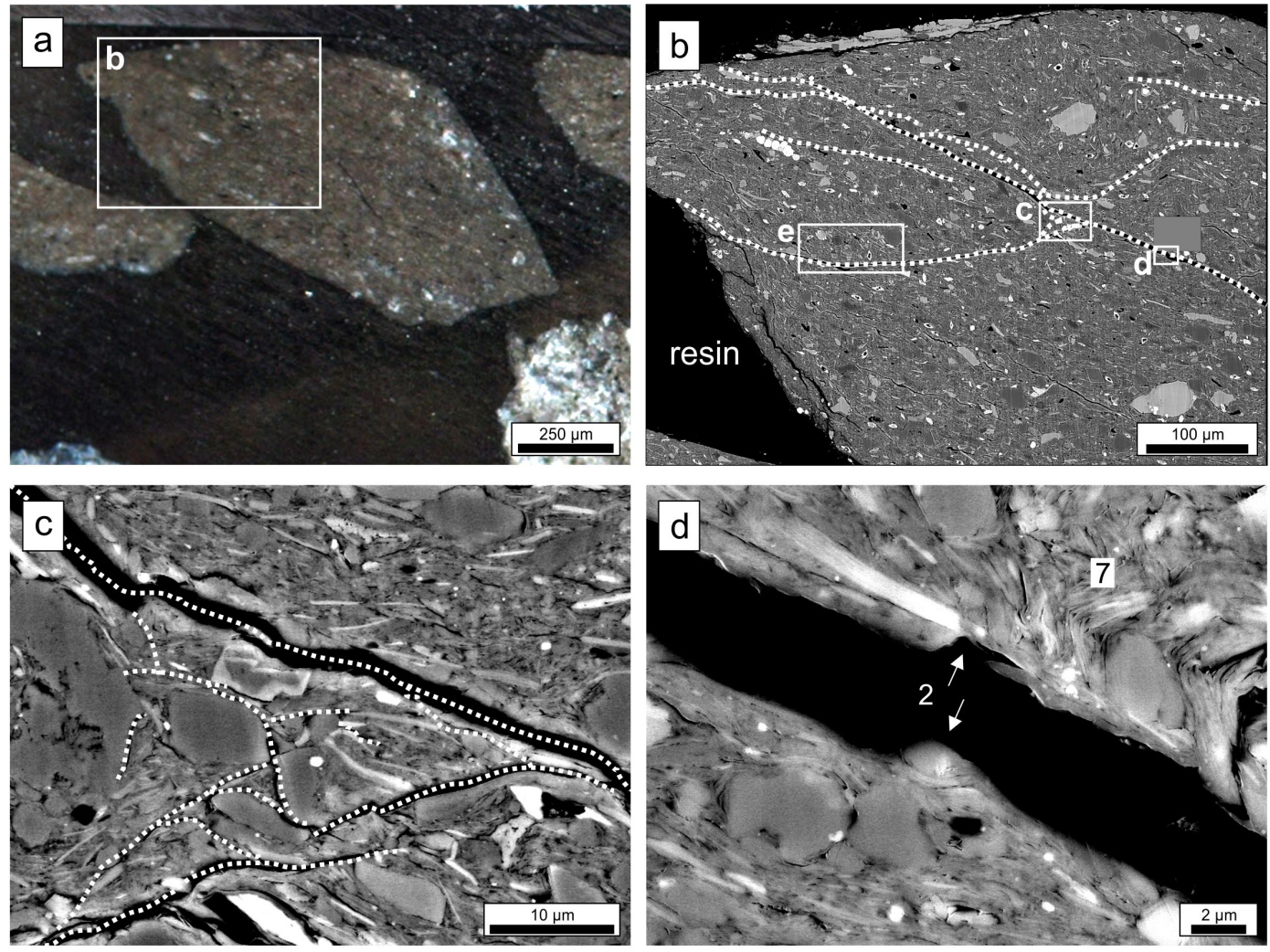

Figure 9. (a) shows a resin-embedded microlithon in RLM. (b)-(d) are BIB-SEM micrograph insets of (a). (b) displays a microlithon with internal shear zones highlighted by dashed lines. (c) is a detail of (b) showing a shear zone junction. (d) is a detail of (b) showing a $\mu$ m-thin, opened microlithon internal shear zone (2). We interpret the shear zone opening as a sampling artefact, with corresponding shapes of the fracture walls (arrows) and bend clay particles in the vicinity of the shear zone (7). Numbering as used in the previous figure. Inset (e) is shown in Fig. 10c.

estimated average shear zone volumes $\left(V_{\mathrm{SZ}-i}\right)$ per bin $(i)$ :

$V_{\text {SZ-total }}=\sum_{i=1}^{\max i} N_{i-\text { calc. }} \times V_{\mathrm{SZ}-i}$.

For this, we considered a simplified, scale-independent average ellipsoid microlithon shape. The average shear zone volume $\left(V_{\mathrm{SZ}-i}\right)$ is calculated by subtracting the average microlithon volume $\left(V_{\mathrm{ML}-i}\right)$ from a version of itself $\left(V_{\mathrm{ML} 2-i}\right)$ that is $10 \mathrm{~nm}$ smaller on each axis (the assessed average shear zone thickness is $10 \mathrm{~nm}$ ):

$$
\begin{aligned}
V_{\mathrm{SZ}-i} & =V_{\mathrm{ML}-i}-V_{\mathrm{ML} 2-i}, \\
V_{\mathrm{ML}-i} & =\frac{4}{3} \times \pi \times a \times b \times c, \\
V_{\mathrm{ML} 2-i} & =\frac{4}{3} \times \pi \times(a-5 \mathrm{~nm}) \times(b-5 \mathrm{~nm}) \\
& \times(c-5 \mathrm{~nm}),
\end{aligned}
$$

where $2 a$ is the length, $2 b$ the width and $2 c$ the microlithon height (Fig. 5c), the latter two given from the above-determined height-to-length and width-to-length ratios.

The calculation gives a shear zone volume $\left(V_{\text {SZ-total }}\right)$ of $0.2 \%$ for sample BFS1-SC1 and $1.3 \%$ for sample BPS12$\mathrm{SC} 1$. For both samples, the sum of all calculated microlithons yields a volume comparable to the original aggregate (a cube with $\sim 13$ and $\sim 15 \mathrm{~cm}$ edge lengths for samples BPSSC1 and BFS1-SC1, respectively). Nevertheless, this geometric approach is a strong simplification to estimate that the strained volume in scaly clay is as low as about $1 \%$. We suggest further studies on microlithon shapes, in particular in $3-\mathrm{D}$, as this study relies on a combination of 2-D sections only.

\section{Discussion}

\subsection{Fabric}

Scaly clay is a prominent and easily recognizable part of the Main Fault. It occurs in elongated bodies of fault rock and is composed of lens-shaped, biconvex, elongated, variably sized microlithons (or phacoids; cf. Bosworth and Vollmer, 

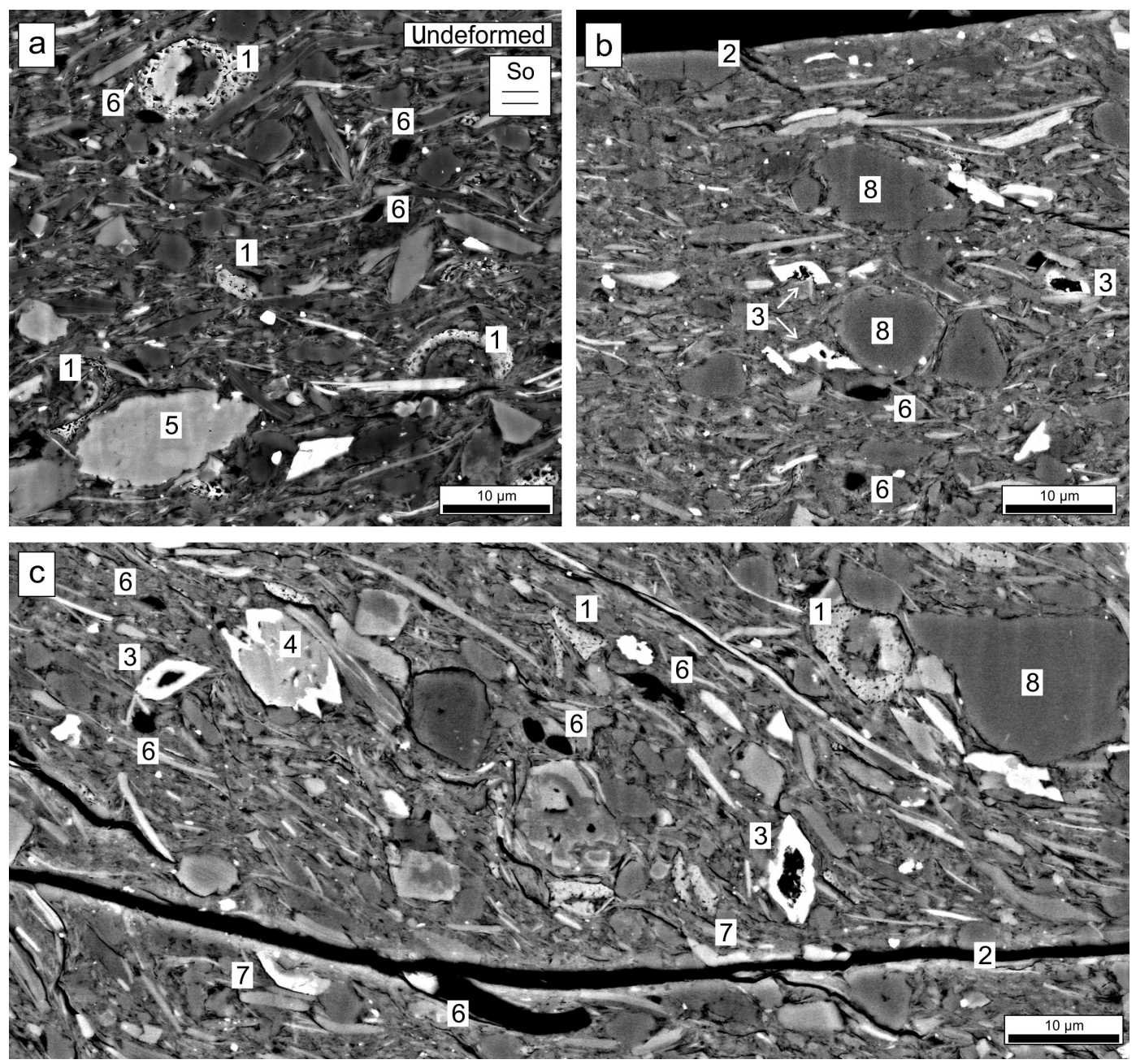

Figure 10. BIB-SEM micrographs comparing an undeformed fabric (a) and microlithon internal fabrics (b) and (c). (a) derives from the sample shown in Fig. 11a. The locations of (b) and (c) are given in Figs. 8b and 9b, respectively. The images show intact to slightly strained fossils (1), $\mu$ m-thin shear zones (2), pores in siderites (3), overgrowth (4), a calcite patch (5), dark OM (6), bend particles in the vicinity of a thin shear zone (7) and lobate $\mathrm{SiO} 2$ grains (8). Numbering is as in the previous figures.

1981; Housen et al., 1996) that are separated by anastomosing thin shear zones and microveins. The microlithons are the building blocks of scaly clay: they are essentially undeformed and quite resistant to further disintegration. Microlithons of all sizes are roughly similar in shape, mostly with their longest axis parallel to the movement direction of the Main Fault (Fig. 12). The slickensides on the microlithons also have this trend (dip-slip), scattered by the anastomosing geometry of the shear zones. The microlithonbounding thin shear zones are $5-10 \mu \mathrm{m}$ wide and identical in microstructure to those reported by Laurich et al. (2014) from the non-scaly parts of the Main Fault in OPA. We are currently investigating whether the evolution of nm-sized clay particles in the slickensided surfaces (Fig. 5f) may involve a combined process of cataclasis and authigenic precipitation from fluids as suggested by Clauer et al. (2017). Moreover, we showed intact and reworked microveins within scaly clay, always bound to shear zones and often in the vicinity of gouge (Figs. 8b, 15). This indicates early to syntectonic vein precipitation. Neither the veins nor the thin shear zones show consistent overprintings and the microfolds are not refolded, suggesting a progressive development of the scaly clay during shearing in the Main Fault. The microlithon size distribution follows a power-law model, with microlithons appearing self-similar, i.e. exhibiting isotropic-scale invariance (sensu Bonnet et al., 2001).

\subsubsection{Comparison to other scaly clays}

Our findings are similar to other scaly clays worldwide: according to the terminology of Vannucchi et al. (2003), the scaly fabric of Opalinus Clay from the Main Fault is defined by partings along localized zones of aligned grains in a matrix of poorly to slightly aligned clay minerals. We identified 

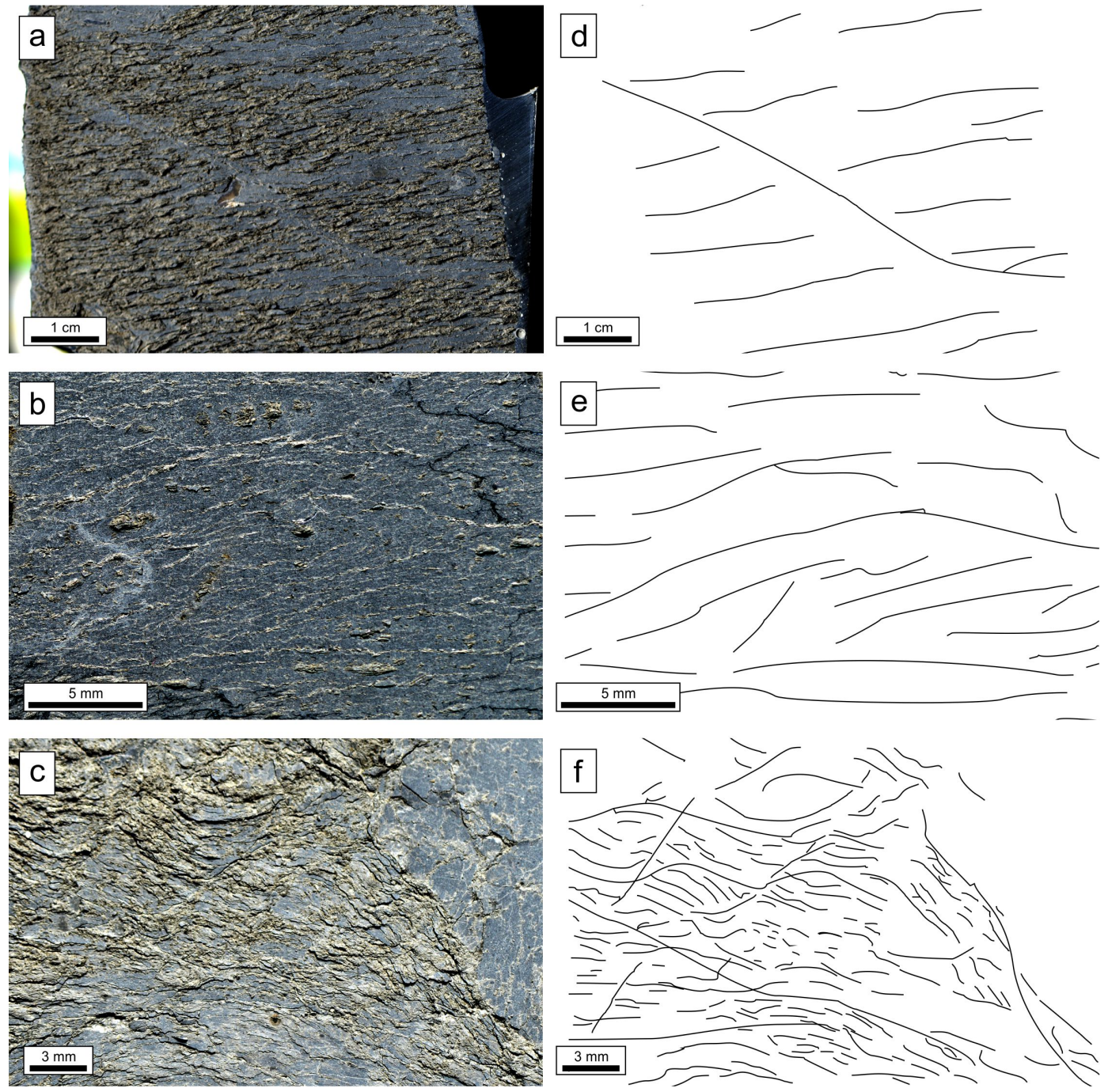

Figure 11. Photographs and sketches of water-immersed samples. (a) Sample V08 showing undeformed bedding foliation and one shear zone, (b) sample V05 showing low strained scaly clay and (c) sample V14 being high strained scaly clay with higher density and complexity of shear zones. The right part in (c) and (f) likely resembles foliation perpendicular to the viewing direction.

these localized zones as $\mu \mathrm{m}$-thin shear zones similar to other scaly clays (e.g. Maltman, 1987) and classify scaly Opalinus Clay as best comparable to scaly clay from the Apennine detachment faults (Coli and Sani, 1990; Vannucchi and Maltman, 2000). Nevertheless, we see similarities (localized particle alignment, anastomosing shear zones, comparable microlithon shapes) also to scaly clays with a higher degree in fabric intensity such as those from tectonic mélanges and submarine accretionary prisms (Agar et al., 1989; Bettelli and Vannucchi, 2003; Chester et al., 2013; Labaume et al., 1997). Similar to all studies on the scaly clays mentioned above, we interpret that finely distributed shearing is the main fabric-generating process, with the occasional occurrence of S-C geometries (sensu Passchier et al., 2005) at various scales. To our knowledge a microlithon size distribution for other scaly clays has never been recorded.

\subsubsection{Microlithon internal deformation}

It is a long-standing debate whether microlithon internal fabric "shows any alignment of phyllosilicates", especially in scaly clay of accretionary prisms (Agar et al., 1989; Labaume et al., 1997; Prior and Behrmann, 1990; Vannucchi et al., 2003; Wallace et al., 2003). Takizawa et al. (1999) and Housen et al. (1996) ask why bulk rock physical properties of scaly clay from the Barbados prism indicate a low degree of preferred particle orientation at depths where deformation appears to be most highly concentrated. A low degree of particle alignment is also found by Morgan and Kraig (1995) for the décollement zone of the Nankai accretionary prism. In contrast, microstructural SEM studies on Barbados scaly clay show strong preferred particle orientations (Cowan et al., 1984; Labaume et al., 1997; Maltman et 


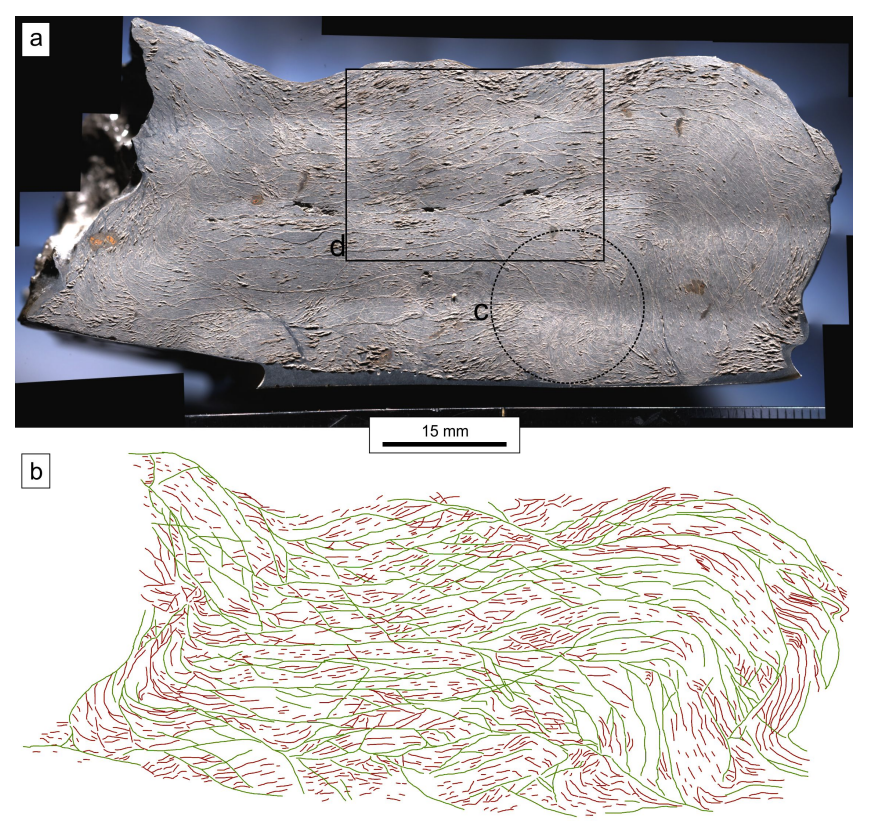

Figure 12. (a) is a shaded light RLM mosaic of a microfold in sample V12. (b) shows foliation interpretations: thin shear zones (green) encasing lensoid microlithons with sub-parallel bedding foliation (red). Note the overthrust-like structure in the microfold hinges on the left and right of the image. Circle (c) is a detail shown in Fig. 13. It derives from the counterpart half of the sample shown here. (d) is shown in Fig. 16.

al., 1997; Moore et al., 1986; Taylor et al., 1990). Our observations have shown that deformation is strongly partitioned into $\mu \mathrm{m}$-thin shear zones of aligned particles, whilst the microlithons remain largely undeformed: we observed in the microlithons intact fossils, similar grain sizes, grain shapes and a similar degree in grain alignment to undeformed fabric from non-scaly Opalinus Clay (Fig. 10).

The network of the shear zones between the microlithons can be a spaced cleavage as shown in Fig. 4a, anastomosing with variable density (Fig. 11) to S-C foliations (Fig. 14) with microfolds (right and left parts in Fig. 12). We also note that in the lens-shaped scaly clay in Fig. 14a the bedding has been rotated to vertical, while in the surrounding undeformed rock the bedding is sub-horizontal, resulting in a kink-like geometry with strong development of scaly clay.

\subsubsection{Different "scaliness"}

In agreement with the above observations, scaly clay can be of different "scaliness", meaning different densities of thin shear zones and thus different microlithon sizes (Fig. 11). However, the volume of shear zones in scaly clay is generally minor (about $1 \mathrm{vol} \%$ ), even for aggregates with a high shear zone density (see above). These findings are in concert with Housen et al. (1996), who proposed that most strain in the
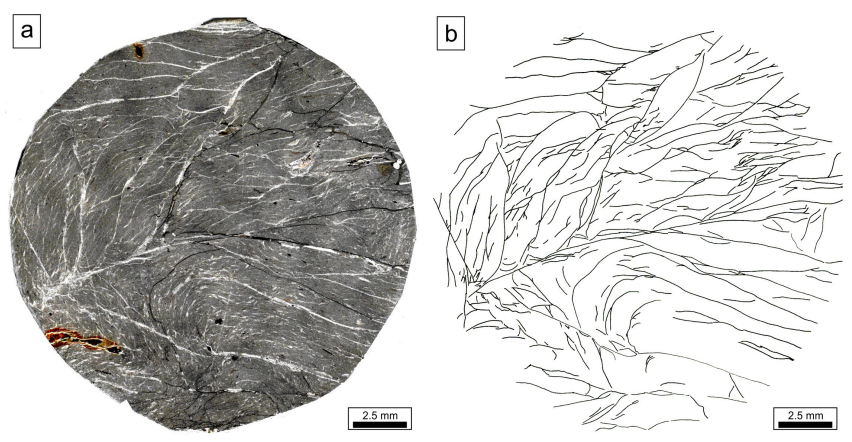

Figure 13. BIB-RLM micrograph and sketch of subsample V12-1 (see Fig. 12 for location). Note the microfold in the lower sample part with bend foliation, while the microlithons in the upper part show a uniform foliation. There is no shear zone overprinting visible.

décollement of the Barbados prism has been accumulated by the volumetrically minor component of shear zones.

We note that the scales of observation used in this study do not yet allow full multiscale mapping of shear zones: it is not yet possible to map all shear zones with sub-micron resolution in the hand specimens which we mapped using optical microscopy.

\subsection{Mechanisms in the evolution of scaly clay}

Even though scaly clays have been extensively studied, a comprehensive mechanical understanding of their evolution is missing. "Scaly clay" is a descriptive term without any genetic connotation and there are many different mechanisms that can produce scaly fabric (cf. Vannucchi et al., 2003). In what follows we discuss and compare possible mechanisms for the evolution of the scaly clay as part of the fault processes in the Main Fault.

\subsubsection{Evolution of the initial segments of the Main Fault}

As a response to tectonic stress, we infer that a series of shallow-dipping, incipient, curved thin shear zones formed the first localization of deformation in the phyllosilicate-rich, slightly overconsolidated OPA. We interpret this as being associated with intense softening in the thin shear zones (Ikari et al., 2011; Ingram and Urai, 1999; Kirkpatrick et al., 2015), caused by collapse of porosity, breakup of cement, alignment of particles and the formation of nanoparticles and perhaps the associated temporary local increase in pore pressure. This localized deformation is interpreted as having interacted with slip along the bedding foliation (Haines et al., 2013; Ikari et al., 2011). In these shear zones it is much easier to keep sliding than to deform the protolith, but the geometry of the shear zones rapidly leads to "locking-up" and associated stress concentrations, which initiate new shear zones. We propose that these initial shear zone networks develop 

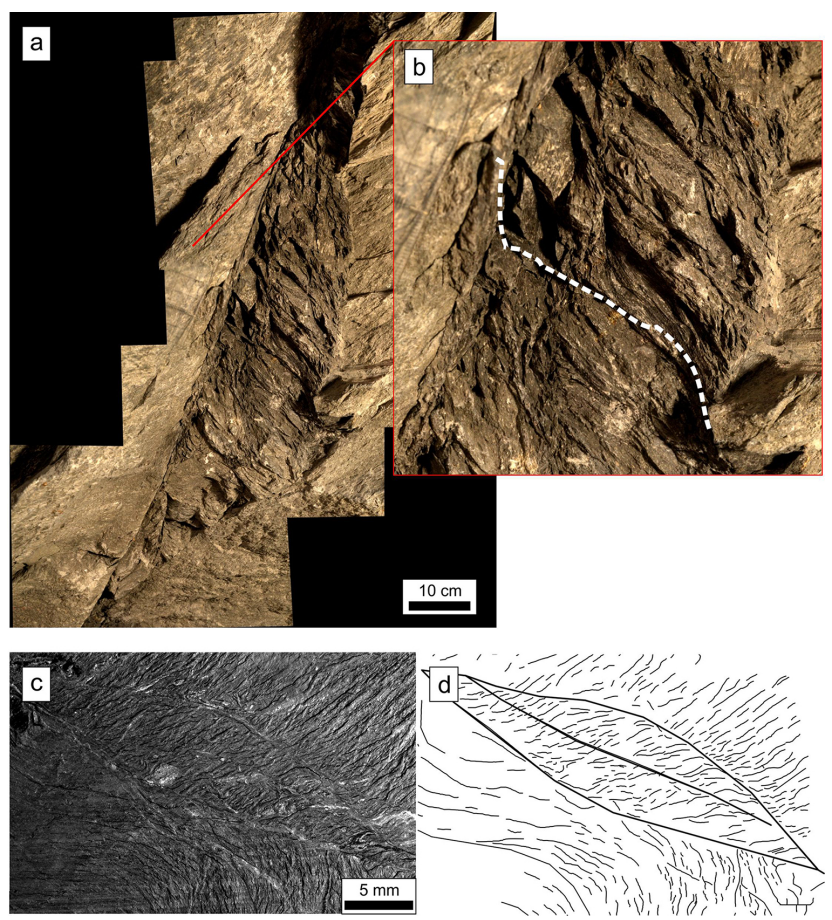

Figure 14. S-C foliations. (a) and (b) in outcrop scale, viewing direction WSW at Gallery 98 (view Fig. 1 for location). (c) and (d) in mm scale in drill core sample BPS12-4 (location shown in Fig. 15).

into fault segments which coalesce during further fault movement. It is the strike and dip relays between these segments (Nicol et al., 2002) that create the boundary conditions for macroscopically continuous deformation by sequentially developing, conjugate shear zones that finally form the scaly clay (cf. Figs. 2 and 14). The proposed evolution is sketched in Fig. 16 and further discussed below.

Some insight into the mechanics of this process may be provided by the results of van der Zee (2001), who found an increased differential stress in the restraining bends that causes a preferred deformation of the relays' interior. The deformation in the relay results in folding of the bedding to a steep orientation aided by slip along bedding, and is accompanied by conjugate shears (stage 2 in Fig. 16): one as bedding parallel offset and the other as bedding perpendicular offset (cf. Carreras et al., 2010; McGrath and Davison, 1995; Nicol et al., 2002; Vollmer and Bosworth, 1984). This way, rhombohedral microlithons (Fig. 4a) similar to the fabric of pencil cleavage (cf. Reks and Gray, 1982) form. However, Fig. 7c shows more elliptically shaped microlithons and Figs. $16 \mathrm{~b}$ and 13 picture more curved shear zones that have been reported for other scaly clays, too. We interpret these as showing that the shear zones formed progressively, with younger shear zone paths being influenced by the reactivation of older shears (stage 3 in Fig. 16). The boundary conditions for this macroscopically continuous deformation are given by the relay between the initial segments (Figs. 12, 13

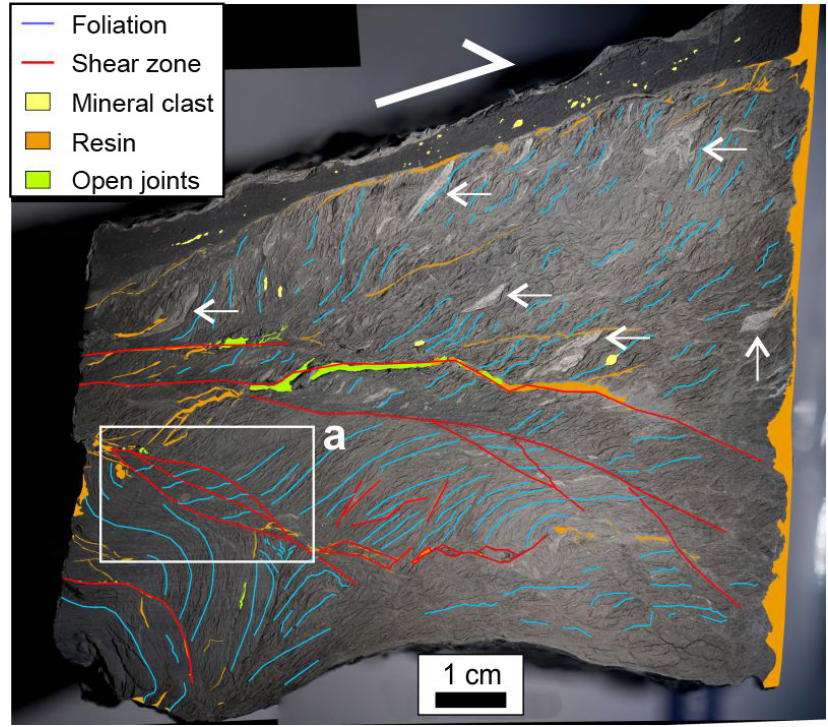

Figure 15. Shaded-light photograph and foliation sketches of waterimmersed sample BPS12-4. Note the dark band of gouge on the sample top and brighter (calcite-rich) areas, indicated by arrows; $\mathrm{a}$ is a detail shown in Fig. 14c and d.

and 15). The interaction of the two sets of shears is illustrated in Fig. 17, showing how progressively smaller microlithons are formed to accommodate deformation around large microlithons. This model is also supported in Fig. 9c, where a curved shear zone splays up next to a through-going shear zone, suggesting a relative age relation of the shears.

The process of progressive slicing up of fragments has been modelled by Sammis and King (2007), who showed the process of collisions of particles in a fault zone which fail by Mode I fracturing. With increasing displacement, they found a power-law particle size distribution with increasing exponents. In the scaly clay of OPA, the fragments fail by shear, and the fragments are increasingly surrounded by the soft material of the shear zones which helps the microlithons flow past each other (Fig. 17). Similar to Sammis and King (2007), this progressive, relay-bound scaly clay generation may lead to increased power-law exponents in microlithon size distribution. Thus, the power-law exponent could be used as an indicator of the degree of deformation, i.e. of the aggregates' scaliness.

In addition to the geometrical locking and fragmentation in a relay as described above, another mechanism is important: the evolution of pore pressure and effective stress. There are two relevant observations for this: the isolated calcite microveins and the network of shear zones with porosity collapse.

\subsubsection{Dependency of strain and pore pressure changes}

We infer that the shear zones in our samples were closed in situ (e.g. Fig. 9d): the fracture with slickensides is interpreted 
a

(1)

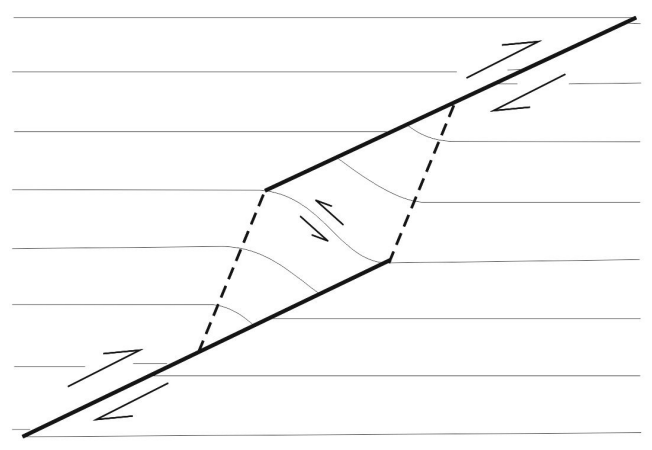

(3)

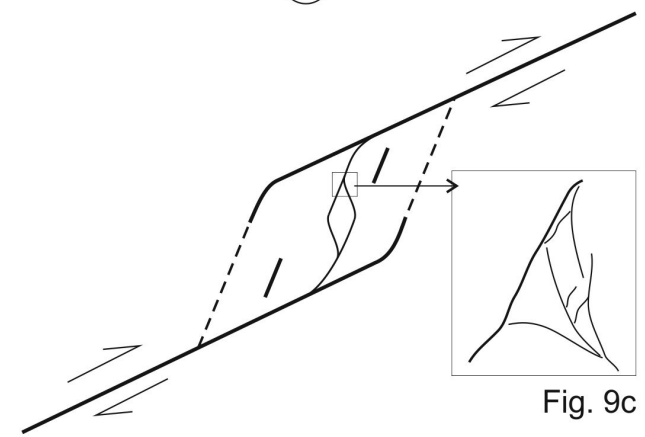

(2)

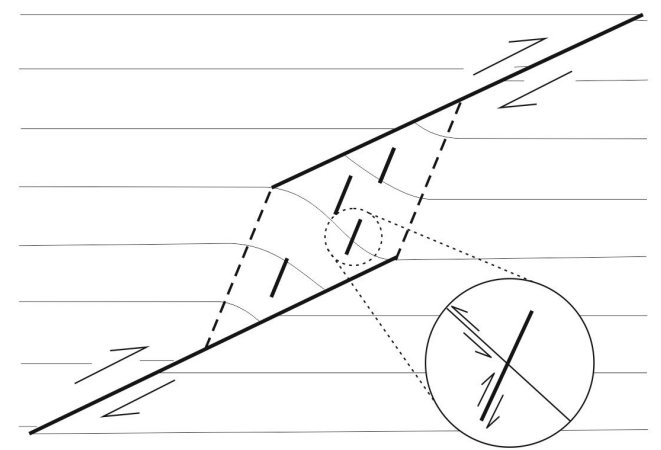

(4)

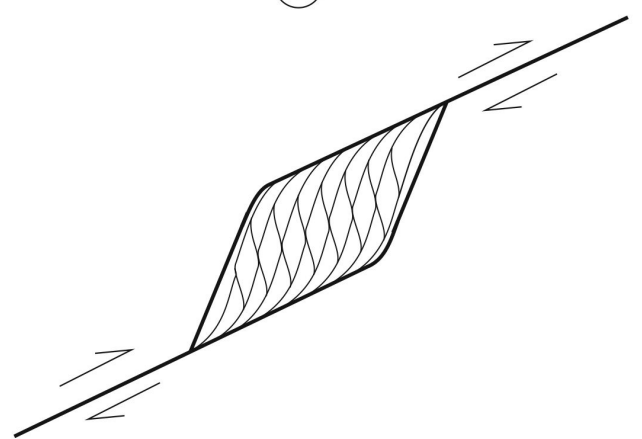

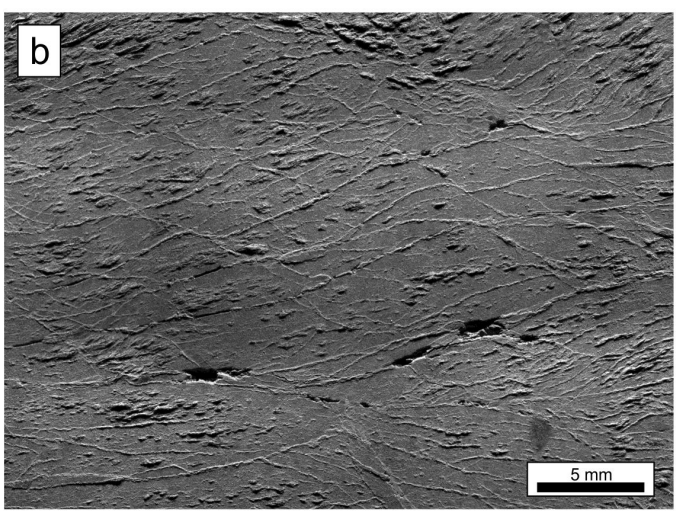

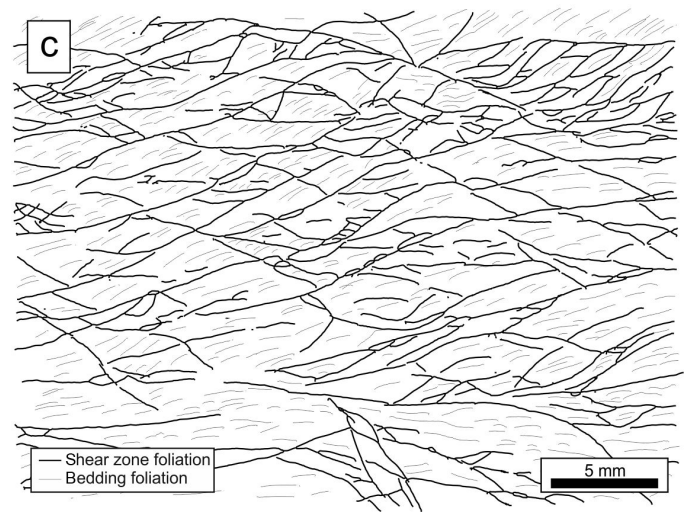

Figure 16. (a) is a simplified mechanical model of the progressive development of anastomosing shear zones. (1) Initial contractional relay (after Nicol et al., 2002) and relay internal development of a kink band by reorientation of bedding (compare to Fig. 14). (2) Development of relay internal R-hears that themselves link as relays (3). The inset compares to shear zones shown in Fig. 9c. (4) Progressive development and linking of further shears. (b) is an inset and (c) a sketch from Fig. 12. Note the similar shear zone patterns of (4) and (c).

to have resulted from excavation damage and sample handling (cf. Prior and Behrmann, 1990). This is supported by the extremely low permeability of the Main Fault shown by measurements in boreholes (Bossart and Wermeille, 2003; Thury and Bossart, 1999). Measurements in deformed Tohoku décollement samples (scaly clay) show a drastic perme- ability decrease perpendicular to shear direction (Ikari et al., 2013). Arch and Maltman (1990) found in laboratory experiments a higher permeability parallel to shear and Casciello et al. (2004) propose a mechanism of "self-lubrication" of the shear zones. 


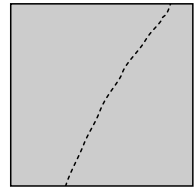

$\mathrm{N}=1$

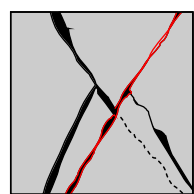

$\mathrm{N}=5$

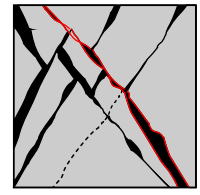

$\mathrm{N}=9$

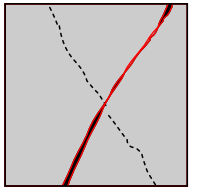

$\mathrm{N}=2$

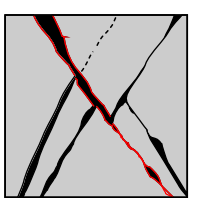

$\mathrm{N}=6$

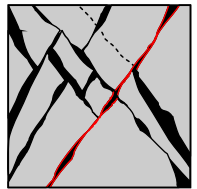

$\mathrm{N}=11$

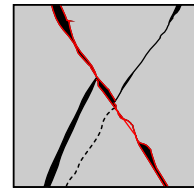

$\mathrm{N}=4$

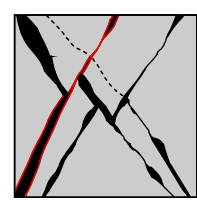

$\mathrm{N}=7$

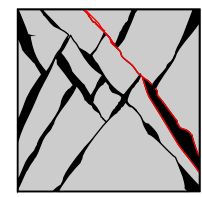

$\mathrm{N}=13$
Figure 17. Simplified mechanical model illustrating a rapidly increasing number of (smaller) microlithons by conjugate shearing. For better visibility, the model exaggerates the shear offset, which might lie in the range of only a few $\mu \mathrm{m}$ for scaly clay shear zones. Shear zone asperities create releasing and restraining bends, the first filled with calcite veins, the latter leading to geometrical "lockingup", causing the development of new (smaller) microlithons.

An interesting problem of scaly clay evolution is thus that during the formation of a shear zone inside a microlithon, the pore collapse may create a temporary, local increase in pore pressure in the microlithons bound by the closed-cell network of shear zones with very low permeability. If the rate of pore pressure generation is faster than the rate at which permeability allows the pore pressure to dissipate, overpressure is generated (Vannucchi et al., 2003). On the other hand, the slight overconsolidation of OPA allowed dilation along some of the shear zones between the microlithons, which can cause rapid local redistribution of fluid and crystallization of the microveins. This, in turn, leads to local, temporary drop in fluid pressure that may promote locking of the shear zones and vein precipitation (cf. the veins in Figs. $8 \mathrm{~b}$ and 15). Moore and Iverson (2002) found stable but episodic slip in ring shear tests of compacted, water saturated granular materials where pore pressure build-up leads to material weakening and shear-induced dilation leads to a decline of fluid pressure with consequent material strengthening. It would be interesting to try to quantify the local heterogeneities in pore pressure in the evolving Main Fault. A starting point for this could be the work of Cuss et al. (2012) reporting heterogeneous pore pressure distributions in clay-rich materials and the work of Amann and Vogelhuber (2015), who have reviewed the geomechanical studies of Opalinus Clay, discussing the many pitfalls of accurately measuring pore pressure during experiments. Although the pore pressure coef- ficients reported by Amann and Vogelhuber (2015) may allow estimation of the local pore pressure increase in the microlithons surrounded by pore-collapsing shear zones, there is no information available on the permeabilities of OPA shear zones. In agreement with our considerations, experiments on Opalinus Clay by Cuss et al. (2011) showed that conductivity decreases at low shear strain and increases at high shear strain due to the development of a complex shear network.

\subsubsection{Evolution of scaly clay}

In the sections above, we discussed how the macroscopically continuous deformation in the scaly clay of the Main Fault in OPA can result from deformation in relays between fault segments. The scaly clay generation is a ductile fragmentation process, where the pattern of shear zone development occurs at increasingly smaller scales. With ongoing evolution, the mechanism will produce smaller and smaller, self-similar appearing microlithons with each step (Fig. 17). Thus, we consider the evolution of scaly clay to be a fractal process within inferred limits from $5000 \mu \mathrm{m}^{2}$ to $160 \mathrm{~cm}^{2}$ microlithon area. The process reduces the amount of larger microlithons, increases the amount of smaller microlithons and thus overall increases the power-law exponent of the microlithon size distribution (Eqs. 2 and 3).

In their review of the scaling of natural fracture systems, Bonnet et al. (2001) state that most common power-law exponents fall in the range of 1.7 to 2.75 , with a greater concentration around 2. The exponent values of the power-law model for the microlithon size distribution presented here fall within the same range (2.09 and 2.34). Bonnet et al. (2001) write further that in physical experiments and numerical simulations, the exponent converges on a value of 2.0 with ongoing fracture system development. Accordingly, as values have a wide range in nature, they suggest that natural systems display a range of maturity stages. We can contribute to this idea by a closer look at the sensitivity of the exponent value to the total sheared volume $\left(V_{\text {SZ-total }}\right)$. Figure $5 \mathrm{~d}$ displays the power-law exponent vs. the shear zone volume as calculated above (Eqs. 5 to 8). For exponents up to 2.0, small microlithons contribute less to the total sample volume than large ones, and hence the strained volume is correspondingly low. On the other hand, for negative exponents larger than 2.0 , the shear zone volume increases drastically due to the increasing contribution of small microlithons with a high relative shear zone volume. With increasing exponents, the shear zone volume converges to $23 \mathrm{vol} \%$, a value that would be realized if the aggregate would consist entirely of microlithons of the smallest considered size $\left(5000 \mu^{2}\right.$; see above). From Fig. 5d we see that microlithon size distributions with an exponent value larger than 2.0 would come with a drastic increase in shear zone volume. A generation of the corresponding many shear zones would require a drastic increase in shear energy. A pure increase in tectonic stress would be 
inadequate to deliver this energy, as a stress increase may lead to brittle, localized failure rather than the macroscopically ductile development of the scaly clay. Hence, we consider a constant stress setting to be necessary for the development in scaly clay. Such a setting may be realized in the relay between fault segments as proposed above.

The activity and propagation of the relay segments control the maturity (i.e. scaliness) of the fabric in between. If one segment becomes inactive and further offset is entirely accommodated on the other, scaly clay generation may be stopped and the fabric may be preserved in a low scaliness state. Alternatively, deformation can be repartitioned and localized deformation of scaly clay may lead to a much higher strain, forming gouge. Gouge has been found next to the scaly clay aggregates in the Main Fault (Fig. 15). We examine gouge in more detail in a follow-up paper.

\section{Conclusions}

Scaly clay aggregates consist of elongated lens-shaped microlithons surrounded by $\mu \mathrm{m}$-thin shear zones. The density of these shears in a scaly aggregate is variable; i.e. the aggregates are of different scaliness (Fig. 11). The shear zones surround microlithons of various sizes which are internally undeformed to slightly deformed (e.g. by bedding parallel shear in flexural slip of microfolds and cleavage development). For two scaly aggregates, we recorded microlithon size distributions that follow power laws with exponents of -2.09 and -2.34 (Fig. 5b). The upper and lower limits of the distributions are not determinable from the data alone. However, we consider the smallest microlithon to be in the range of only a few grains high $(\sim 50 \mu \mathrm{m})$ and the largest of the order of $10 \mathrm{~cm}$ in length, based on SEM and outcrop observations, respectively. The determined power-law exponent allows estimation of the total deformed volume in the scaly clay aggregates, which is as small as $\sim 1 \mathrm{vol} \%$.

Scaly clay from the Main Fault is highly deformed Opalinus Clay, formed by the progressive interaction of thin shear zones to generate new ones, evolving into a network of anastomosing shear zones between microlithons. We infer that scaly clay formed by finely distributed ductile shear, in a fault relay deforming between segments of the evolving Main Fault. The extreme partitioning of strain is related to the very intense softening in the already anisotropic OPA, caused by collapse of porosity, breakup of cement, alignment of particles and the formation of nanoparticles and a possible associated local increase in pore pressure.

Our microstructural observations of tight, non-porous shear zones are in good agreement with the extremely low permeability of the Main Fault at present $\left(1 \times 10^{-13} \mathrm{~m} \mathrm{~s}^{-1}\right.$, Bossart and Wermeille, 2003).

Extrapolation of laboratory deformation experiments to predict the long-term mechanical properties of faults in OPA requires incorporation of the different deformation mechanisms between laboratory and natural deformation.

Scaly clay from the Main Fault in the Mont Terri Rock Laboratory is similar to other scaly clays worldwide in the sense of finely distributed ductile shear around essentially undeformed, lens-shaped microlithons. But particularly remarkable is that an intense scaliness occurs with such a small inferred offset $(10 \mathrm{~m})$. A comparison with microlithon size distributions of other scaly clays is a promising new line of research.

\section{The Supplement related to this article is available online at doi:10.5194/se-8-27-2017-supplement.}

Acknowledgements. We would like to thank the staff at Mont Terri for their continuing valuable on-site support, Guillaume Desbois for discussion on the microlithon size distribution and Werner Kraus for his tips in sample preparation. This work was funded by Swisstopo via the Mont Terri Consortium. We further thank editor Renée Heilbronner as well as Werner Gräsle and a second anonymous reviewer for their constructive comments. Werner Gräsle gave valuable input on statistical analysis by personal discussion.

Edited by: R. Heilbronner

Reviewed by: W. Graesle and one anonymous referee

\section{References}

Agar, S. M., Prior, D. J., and Behrmann, J. H.: Back-scattered electron imagery of the tectonic fabrics of some fine-grained sediments: Implications for fabric nomenclature and deformation processes, Geology 17, 901-904, doi:10.1130/00917613(1989)017<0901, 1989.

Amann, F. and Vogelhuber, M.: Expert Report - Assessment of Geomechanical Properties of Intact Opalinus Clay, 2015.

Arch, J. and Maltman, A.: Anisotropic permeability and tortuosity in deformed wet sediments, J. Geophys. Res.-Earth, 95, 90359045, doi:10.1029/JB095iB06p09035, 1990.

Bettelli, G. and Vannucchi, P.: Structural stlyle of the offscraped Ligurian oceanic sequences of the Northern Apennines: New hypothesis concening the development concerning the development of melange block-in-matrix fabric, J. Struct. Geol., 25, 371-388, doi:10.1016/S0191-8141(02)00026-3, 2003.

Bonnet, E., Bour, O., Odling, N. E., Davy, P., Main, I., Cowie, P., and Berkowitz, B.: Scaling of fracture systems in geological media, Rev. Geophys., 39, 347-383, doi:10.1029/1999RG000074, 2001.

Bossart, P. and Wermeille, S.: Paleohydrological Study on the Surroundings of the Mont Terri Rock Laboratory, in: Mont Terri Project - Geology, Paleohydrology and Stress Field of the Mont Terri Region, Geology Series, edited by: Heitzmann, P. and Tripet, J.-P., Federal Office for Water and Geology, Bern-Ittigen, 45-64, 2003. 
Bosworth, W. and Vollmer, F. W.: Structures of the medial Ordovician flysch of eastern New York: deformation of synorogenic deposits in an overthrust environment, 89, J. Geol., 551-568, 1981.

Brittain, H. G.: Particle-Size Distribution II: Powdered Solids of sampling powdered solids, Pharm. Phys., 2, 1-5, 2002.

Carreras, J., Czeck, D. M., Druguet, E., and Hudleston, P. J.: Structure and development of an anastomosing network of ductile shear zones, J. Struct. Geol. 32, 656-666, doi:10.1016/j.jsg.2010.03.013, 2010.

Casciello, E., Cesarano, M., and Cosgrove, J. W.: Shear deformation of pelitic rocks in a large-scale natural fault, Geol. Soc. Spec. Publ. 224, 113-125., doi:10.1144/GSL.SP.2004.224.01.08, 2004.

Chester, F. M., Rowe, C., Ujiie, K., Kirkpatrick, J., Regalla, C., Remitti, F., Moore, J. C., Toy, V., Wolfson-Schwehr, M., Bose, S., Kameda, J., Mori, J. J., Brodsky, E. E., Eguchi, N., and Toczko, S.: Structure and composition of the plate-boundary slip zone for the 2011 Tohoku-Oki earthquake, Science, 342, 1208-1211, doi:10.1126/science.1243719, 2013.

Clauer, N., Techer, I., Nussbaum, C., and Laurich, B.: Geochemical signatures of paleofluids in calcite from microstructures and matrix of the Main Fault in the Opalinus Clay: A contribution to the regional evolutionary model, Swiss J. Geosci., accepted, 2017.

Coli, M. and Sani, F.: Vein distribution in a thrust zone; a case history from the Northern Apennines, Italy Deformation mechanisms, rheology and tectonics, Geol. Soc. Spec. Publ., 54, 475482, doi:10.1144/GSL.SP.1990.054.01.43, 1990.

Cowan, D., Moore, J., Roeske, S. M., Lundberg, N., and Lucas, S. E.: Structural features at the deformation front of the Barbados Ridge Complex, Deep Sea Drilling Project LEG 78A, Initial Reports Deep Sea Drill, 78 535-548, doi:10.2973/dsdp.proc.78a.127.1984, 1984.

Cuss, R. J., Milodowski, A., and Harrington, J. F.: Fracture transmissivity as a function of normal and shear stress: First results in Opalinus Clay, Phys. Chem. Earth, 36, 1960-1971, doi:10.1016/j.pce.2011.07.080, 2011.

Cuss, R. J., Harrington, J. F., Graham, C. C., Sathar, S., and Milodowski, A. E.: Observations of heterogeneous pore pressure distributions in clay-rich materials, Mineral. Mag., 76, 31153129, doi:10.1180/minmag.2012.076.8.26, 2012.

Dehandschutter, B., Vandycke, S., Sintubin, M., Vandenberghe, N., and Wouters, L.: Brittle fractures and ductile shear bands in argillaceous sediments: Inferences from Oligocene Boom Clay (Belgium), J. Struct. Geol., 27, 1095-1112, doi:10.1016/j.jsg.2004.08.014, 2005.

Desbois, G., Urai, J. L., and Kukla, P. A.: Morphology of the pore space in claystones - evidence from BIB/FIB ion beam sectioning and cryo-SEM observations, eEarth Discuss., 4, 1-19, doi:10.5194/eed-4-1-2009, 2009.

Haines, S. H., Kaproth, B., Marone, C., Saffer, D., and Van der Pluijm, B.: Shear zones in clay-rich fault gouge: A laboratory study of fabric development and evolution, J. Struct. Geol., 51, 206-225, doi:10.1016/j.jsg.2013.01.002, 2013.

Hemes, S., Desbois, G., Urai, J. L., Craen, M. De, and Honty, M.: Variations in the morphology of porosity in the Boom Clay Formation: insights from 2-D high resolution BIB-SEM imaging and Mercury injection Porosimetry, Netherlands, J. Geosci., 92, 275300,2013
Houben, M. E.: In situ characterization of the microstructure and porosity of Opalinus Clay (Mont Terri Rock Laboratory, Switzerland), 2013.

Houben, M. E., Desbois, G., and Urai, J. L.: Pore morphology and distribution in the Shaly facies of Opalinus Clay (Mont Terri, Switzerland): Insights from representative 2-D BIB-SEM investigations on $\mathrm{mm}$ to $\mathrm{nm}$ scale, Appl. Clay Sci., 71, 82-97, doi:10.1016/j.clay.2012.11.006, 2013.

Housen, B. A., Tobin, H. J., Labaume, P., Leitch, E. C., and Maltman, A. J.: Strain decoupling across the decollement of the Barbados accretionary prism, Geology, 24, 127-130, 1996.

Ikari, M., Kameda, J., and Kopf, A.: Frictional behavior of the plate boundary décollement zone in the Japan Trench, sampled during the Japan Trench Fast Drilling Project (JFAST): Implications for shallow coseismic slip propagation, in: EGU General Assembly Conference Abstracts, 2013

Ikari, M. J., Marone, C., and Saffer, D. M.: On the relation between fault strength and frictional stability, Geology, 39, 83-86, doi:10.1130/G31416.1, 2011.

Ingram, G. M. and Urai, J. L.: Top-seal leakage through faults and fractures: the role of mudrock properties, Geol. Soc. Spec. Publ., 158, 125-135, doi:10.1144/GSL.SP.1999.158.01.10, 1999.

Ismat, Z.: Block-supported cataclastic flow within the upper crust, J. Struct. Geol., 56, 118-128, doi:10.1016/j.jsg.2013.08.010, 2013.

Kirkpatrick, J. D., Rowe, C. D., Ujiie, K., Moore, J. C., Regalla, C., Remitti, F., Toy, V., Wolfson-Schwehr, M., Kameda, J., Bose, S., and Chester, F. M.: Structure and lithology of the Japan Trench subduction plate boundary fault, Tectonics, 34, 53-69, doi:10.1002/2014TC003695, 2015.

Klaver, J., Desbois, G., Urai, J. L., and Littke, R.: BIB-SEM study of the pore space morphology in early mature Posidonia Shale from the Hils area, Germany, Int. J. Coal. Geol. 103, 12-25, doi:10.1016/j.coal.2012.06.012, 2012.

Labaume, P., Maltman, A. J., Bolton, A., Tessier, D., Ogawa, Y., and Takizawas, S.: Scaly fabrics in sheard clays from the decollement zone of the Barbados accretionary prism, in: Proceedings of the Ocean Drilling Program, edited by: Shipley, T. R., Ogawa, Y., Blum, P., and Bahr, J. M., 59-77, 1997.

Laurich, B.: Evolution of microstructure and porosity in faulted Opalinus Clay, RWTH-Aachen University, 2015.

Laurich, B., Urai, J. L., Desbois, G., Vollmer, C., and Nussbaum, C.: Microstructural evolution of an incipient fault zone in Opalinus Clay: Insights from an optical and electron microscopic study of ion-beam polished samples from the Main Fault in the Mt-Terri underground research laboratory, J. Struct. Geol., 67, 107-128, doi:10.1016/j.jsg.2014.07.014, 2014.

Maltman, A. J.: Shear zones in argillaceous sediments-an experimental study, Geol. Soc. Spec. Publ., 29, 77-87, doi:10.1144/GSL.SP.1987.029.01.08, 1987.

Maltman, A., Labaume, P., and Housen, B.: Structural geology of the décollement at the toe of the Barbados accretionary prism, Proc. Ocean Drill. Program. Sci. Results, 156, 279-292, 1997.

Mazurek, M., Alt-Epping, P., Bath, A., Gimmi, T., Waber, H. N., Buschaert, S., Cannière, P. De, Craen, M. De, Gautschi, A. Savoye, S., Vinsot, A., Wemaere, I., and Wouters, L.: Natural tracer profiles across argillaceous formations, Appl. Geochem., 26, 1035-1064, doi:10.1016/j.apgeochem.2011.03.124, 2011.

Mazurek, M., Hurford, A. J., and Leu, W.: Unravelling the multistage burial history of the Swiss Molasse Basin: integration 
of apatite fission track, vitrinite reflectance and biomarker isomerisation analysis, Basin Res., 18, 27-50, doi:10.1111/j.13652117.2006.00286.x, 2006.

McGrath, A. G. and Davison, I.: Damage zone geometry around fault tips, J. Struct. Geol., 17, 1011-1024, doi:10.1016/01918141(94)00116-H, 1995.

Moore, J. C., Roeske, S., Cowan, D. S., Lundberg, N., Gonzales, E., Schoonmaker, J., and Lucas, S. E.: Scaly fabrics from Deep Sea Drilling Project cores from forearcs, Geol. Soc. Am. Mem., 166, 55-74, doi:10.1130/MEM166-p55, 1986.

Moore, P. L. and Iverson, N. R.: Slow episodic shear of granular materials regulated by dilatant strengthening, Geology, 30, 843, doi:10.1130/0091-7613(2002)030< 0843:SESOGM> 2.0.CO;2, 2002.

Morgan, J. K. and Karig, D. E.: Décollement processes at the Nankai accretionary margin, southeast Japan: Propagation, deformation, and dewatering, J. Geophys. Res., 100, 15221, doi:10.1029/95JB00675, 1995.

Nicol, A., Gillespie, P. A., Childs, C., and Walsh, J. J.: Relay zones between mesoscopic thrust faults in layered sedimentary sequences, J. Struct. Geol., 24, 709-727, doi:10.1016/S01918141(01)00113-4, 2002.

Nussbaum, C., Bossart, P., Amann, F., and Aubourg, C.: Analysis of tectonic structures and excavation induced fractures in the Opalinus Clay, Mont Terri underground rock laboratory (Switzerland), Swiss J. Geosci. 104, 187-210, doi:10.1007/s00015-011-0070-4, 2011.

Nussbaum, C., Kloppenburg, A., Caer, T., and Bossart, P.: Tectonic evolution of the Mont Terri region, northwestern Swiss Jura: constraints from kinematic forward modelling, Swiss, J. Geosci., accepted, 2017.

Passchier, C. W. and Trouw, R. A. J.: Microtectonics, 2nd Edn., Springer-Verlag, Berlin/Heidelberg, doi:10.1007/3-540-293590, 2005.

Pearson, F. J., Arcos, D., Bath, A., Boisson, J., Fernandez, A. M., Gäbler, H., Gaucher, E., Gautschi, A., and Griffault, L.: Mont Terri Project: Geochemistry of Water in the Opalinus Clay Formation at the Mont Terri Rock Laboratory, 5th Edn., Federal Office for Water and Geology, Bern-Ittigen, 2003.

Prior, D. J. and Behrmann, J. H.: Thrust-related mudstone fabrics from the Barbados Forearc: A backscattered scanning electron microscope study, J. Geophys. Res., 95, 9055, doi:10.1029/JB095iB06p09055, 1990.

Reks, I. J. and Gray, D. R.: Pencil structure and strain in weakly deformed mudstone and siltstone, J. Struct. Geol., 4, 161-176, doi:10.1016/0191-8141(82)90025-6, 1982.

Rübel, A. P., Sonntag, C., Lippmann, J., Pearson, F. J., and Gautschi, A.: Solute transport in formations of very low permeability: Profiles of stable isotope and dissolved noble gas contents of pore water in the Opalinus Clay, Mont Terri, Switzerland, Geochim. Cosmochim. Ac., 66, 1311-1321, doi:10.1016/S00167037(01)00859-6, 2002.
Rutter, E. H., Holdsworth, R. E., and Knipe, R. J.: The nature and tectonic significance of fault-zone weakening: an introduction, Geol. Soc. Spec. Publ., 186, 1-11, doi:10.1144/GSL.SP.2001.186.01.01, 2001.

Sammis, C. G. and King, G. C. P.: Mechanical origin of power law scaling in fault zone rock, Geophys. Res. Lett., 34, 2-5, doi:10.1029/2006GL028548, 2007.

Takizawa, S. and Ogawa, Y.: Dilatant clayey microstructure in the Barbados décollement zone, J. Struct. Geol. 21, 117-122, 1999.

Taylor, E., Burkett, P. J., Wackier, J. D., and Leonard, J. N.: Physical Properties and Microstructural Response of Sediments to Accretion-Subduction: Barbados Forearc, in: Microstructure of Fine-Grained Sediments, edited by: Bennett, R. H., Bryant, W. R., and Hulbert, M. H., Springer-Verlag, New York, 213-228, 1990.

Thury, M. and Bossart, P.: The Mont Terri rock laboratory, a new international research project in a Mesozoic shale formation, in Switzerland, Eng. Geol., 52, 347-359, doi:10.1016/S00137952(99)00015-0, 1999.

Ujiie, K., Tanaka, H., Saito, T., Tsutsumi, A., Mori, J. J., Kameda, J., Brodsky, E. E., Chester, F. M., Eguchi, N., and Toczko, S.: Low coseismic shear stress on the Tohoku-Oki megathrust determined from laboratory experiments, Science, 342, 1211-1214, doi:10.1126/science.1243485, 2013.

van der Zee, W.: Dynamics of fault gouge development in layered sand-clay sequences, RWTH Aachen, 2001.

Vannucchi, P. and Maltman, A. J.: Insights into shallow-level processes of mountain building from the Northern Apennines, Italy, J. Geol. Soc. London, 157, 105-120, doi:10.1144/jgs.157.1.105, 2000.

Vannucchi, P., Maltman, A., Bettelli, G., and Clennell, B.: On the nature of scaly fabric and scaly clay, J. Struct. Geol., 25, 673688, doi:10.1016/S0191-8141(02)00066-4, 2003.

Vitone, C., Viggiani, G., Cotecchia, F., and Hall, S. A.: Localized deformation in intensely fissured clays studied by 2-D digital image correlation, Acta Geotech., 8, 247-263, doi:10.1007/s11440013-0208-9, 2013.

Vollmer, F. W. and Bosworth, W.: Formation of melange in a foreland basin overthrust setting; example from the Taconic Orogen, Melanges, their nature, Orig. significance, doi:10.1130/SPE198p53, 1984.

Wallace, G., Moore, J. C., and Dileonardo, C. G.: Controls on localization and densi cation of a modern de'collement: Northern Barbados accretionary prism, America (NY), 288-297, 2003. 